\title{
Chapter 3 \\ Status Quo of Ethics and Morality in EU \\ Law
}

After this introduction into the relevant basics of normative ethics, let us turn to the status quo of EU law referring to ethics and morality. Following the hierarchy of EU law, let us first have a look at primary EU law. ${ }^{1}$

\subsection{Constitutional Perspective: The Status Quo of Morality in Primary EU Law}

\subsection{1 'United in Diversity'}

The EU's approach to ethics can best be described by its motto 'united in diversity'. On the one hand ('EU united'), the Treaty on European Union draws inspiration "from the cultural, religious and humanist inheritance of Europe"2 and the EU Charter of Fundamental Rights which refers to the Union's "common values"3 and "spiritual and moral heritage". ${ }^{4}$ On the other hand the CFR requires the EU to respect "the diversity of the cultures and traditions of the peoples of Europe as well as the national identities of the Member States"' ('EU in diversity').

Initially, EU integration was an economic vehicle, which developed from coal and steel to an internal market, and finally to a political Union (also safeguarding fundamental rights). The internal market is still a key objective of the EU. Nonetheless, on an exceptional basis, MS are allowed to restrict the free movement of goods based on grounds of "public morality, public policy [and so forth]" (Art 36 TFEU).

\footnotetext{
${ }^{1}$ The following chapter is strongly based on the starting point of this research project, i.e. Frischhut (2015).

${ }^{2}$ Recital 2 TEU.

${ }^{3}$ Recital 1 CFR.

${ }^{4}$ Recital 2 CFR.

${ }^{5}$ Recital 3 CFR. See also recital 6 CFR, Art 3(3)(4) and Art 4(2) TEU. 
The term of 'public morality' itself is not defined in the Treaties. As a notion of EU law, it is interpreted by the CJEU. The Court leaves it to the MS to apply their understanding of public morality, as long as they do not follow a principle of public double morality. ${ }^{6}$

\subsubsection{National Umbrella Philosophy}

With the expanding case-law of the CJEU interpreting the fundamental freedoms of the internal market, some MS sought to protect their nationally determined understanding of morality. A look at the timeline exhibits the contemporaneity of a famous Irish abortion case ${ }^{7}$ (4.10.1991) and the Maastricht Treaty ${ }^{8}$ (signed on 7.2.1992), where one of the protocols to this Treaty provides an umbrella, protecting "Article 40.3.3 [right to life of the unborn] of the Constitution of Ireland". 9

When Malta acceded to the EU in 2004, a similar protocol was annexed to the Accession Treaty, stating that "[n]othing [...] shall affect the application in the territory of Malta of national legislation relating to abortion". ${ }^{10}$ Although those two instances operated without explicit reference to public morality, the intention was the same, as in the following examples.

In the very same round of accessions, Poland opted for a similar, yet different approach. This can be qualified as "less" in terms of legal significance, as Poland's concerns were only taken into account in terms of a Declaration of that acceding state. However, at the same time, it can be seen as 'broader', in the sense that the wording states as follows: "nothing [...] prevents the Polish State in regulating questions of moral significance, as well as those related to the protection of human life". ${ }^{11}$

With the entering into force of the Lisbon Treaty ${ }^{12}$ (1.12.2009), the previously only solemnly proclaimed ${ }^{13}$ CFR became legally binding. ${ }^{14}$ In this context, Poland seemed to fear that the $\mathrm{CFR}^{15}$ "might be used to challenge its freedom to regulate the availability of abortions, euthanasia and same-sex marriage". ${ }^{16}$ Therefore, the final

${ }^{6}$ CJEU Conegate, 121/85, para 20.

${ }^{7}$ CJEU judgment of 4 October 1991, Society for the Protection of Unborn Children [SPUC], C159/90, EU:C:1991:378.

${ }^{8}$ OJ 1992 C 191/1.

${ }^{9}$ OJ 1992 C 191/94.

${ }^{10}$ OJ 2003 L 236/1 (947).

${ }^{11}$ OJ 2003 L 236/1 (983); emphasis added; see also 978.

${ }^{12}$ OJ 2007 C 306/1.

${ }^{13}$ OJ 2000 C 364/1 (Nice, 7.12.2000) and OJ 2007 C 303/1 (Strasbourg, 12.12.2007).

${ }^{14}$ Art 6(1) TEU.

${ }^{15}$ For the application of the CFR on Poland and the United Kingdom see Protocol 30, OJ 2007 C306/156; see also CJEU judgment of 21 December 2011, N. S., C-411/10 and C-493/10, EU:C:2011:865, paras 116-117; Arnull (2014, pp. 1595-1596).

${ }^{16}$ Arnull (2014, p. 1601). Nowadays, on same sex-marriage and EU citizenship, see CJEU judgment of 5 June 2018, Coman, C-673/16, EU:C:2018:385. 
Public morality (not defined) as reason of justification in the context of the free movement of goods (Art. 36 TFEU)

Nothing in Treaties shall affect nat. law concerning "questions of moral significance" and "the protection of human life" (Declaration Accession Treaty 2003) affect Irish constit. law concerning abortion (Prot. Maastricht Treaty 1992)

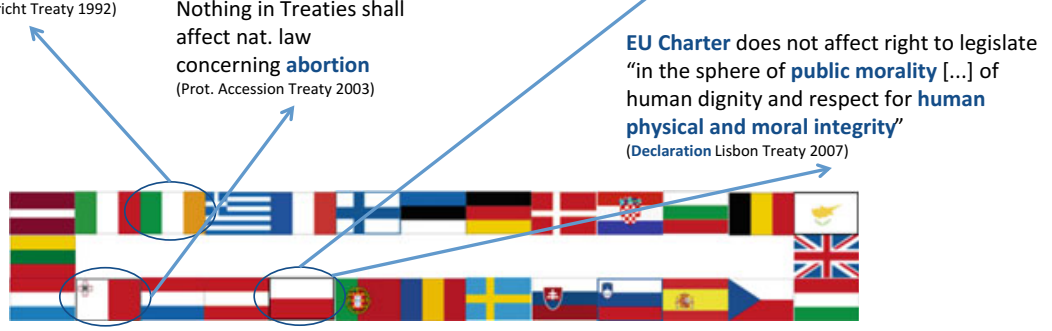

Fig. 3.1 National umbrella philosophy

act of the 13.12.2007 signed Lisbon Treaty contained a declaration by Poland on the CFR, whereby " $[\mathrm{t}]$ he Charter does not affect in any way the right of Member States to legislate in the sphere of public morality, family law, as well as the protection of human dignity and respect for human physical and moral integrity". ${ }^{17}$ Some MS, those present at the time of accession, were united in a position diverse to the Polish one, by underlying in a joint declaration "that the Declarations attached to this Final Act cannot be interpreted or applied in a way contrary to the obligations of the Member States arising from the Treaty and Act of Accession". ${ }^{18}$

As we have seen (see also Fig. 3.1), EU primary law does not comprise the term ethics, but 'public morality'. ${ }^{19}$ This notion is a public one, that is to say a collective one, as it is defined by public authorities, not by individuals. We have seen both implicit (in the context of abortion) and explicit reference to public morality.

Has this term been determined regarding its content in EU primary law? No, there are no explicit definitions, most likely because there seems to be, at least a minimum, consensus and the fact that the term of public morality has already been shaped regarding its content by the CJEU. If not defined, is it used in a way, which provides sufficient clarification (i.e. objective 1 of this book)? Due to the historic background and the context of abortion, this second question can be answered in the affirmative.

Nonetheless, the way in which this term of public morality is used cannot be qualified as very ambitious. Quite the opposite, this approach of the "Masters of the

\footnotetext{
${ }^{17}$ OJ 2007 C 306/1 (270), emphasis added.

${ }^{18}$ OJ 2003 L 236/1 (983); and noting "that the Commission subscribes fully to the above".

${ }^{19}$ The "spiritual and moral heritage" (recital 2 CFR) has already been mentioned. The CFR further mentions the "physical, mental, moral or social development" in the context of the prohibition of child labour and protection of young people at work (Art 32(2)). Finally, yet importantly, Art 165(2) TFEU refers to the "physical and moral integrity of sportsmen and sportswomen".
} 
Treaties" can be qualified as an "umbrella philosophy", trying to establish a "principle of non-interference" of EU law with their nationally determined morality. ${ }^{20}$ However, ethics and morality should definitely be more than a mere substitute for a kind of subsidiarity principle.

\subsubsection{Excursus: EU Values}

EU values ${ }^{21}$ are not of relevance for our topic in terms of direct references to ethics or morality. However, Art 2 TEU, which enshrines the values of the EU, is of utmost importance for our topic in an indirect way. This provision has been inserted by the Lisbon Treaty, which entered into force on 1 December 2009, and reads as follows:

The Union is founded on the values of respect for human dignity, freedom, democracy, equality, the rule of law and respect for human rights, including the rights of persons belonging to minorities.

These values are common to the Member States in a society in which pluralism, nondiscrimination, tolerance, justice, solidarity and equality between women and men prevail.

The first sentence states the values which according to the wording are pre-existing ("founded on"), however, does not further define them. The second sentence seems to have a different legal significance, as the wording does not refer to the EU, but to the MS, precisely their society. Perhaps one would expect a plural here, but the second sentence speaks of "a society". According to Pechstein, this formulation fluctuates between (desirably guided) description and prescription, ${ }^{22}$ and can be seen as 'less', as it cannot trigger Art 7 TEU (sanctions in case of violations of values). ${ }^{23}$

Hermerén has emphasized that the common values are "one of several ways of keeping the member states of the European Union together by referring to values they have in common and by pointing out differences between these values and others". ${ }^{24}$ These general common values of the EU have been applied to two areas (digitalization and non-financial reporting, partly in sports) and further specified in others (health and partly in sports), as can be seen below from Table 3.1.

In 2006, thus three years before the entry into force of the Lisbon Treaty, the EU health ministers declared the health values of "universality, access to good quality care, equity, and solidarity". ${ }^{25}$ This example is not an application of the general values, but a concretization, resulting in mainly distinct values, where only solidarity

\footnotetext{
${ }^{20}$ Frischhut (2015, p. 544).

${ }^{21}$ For further details, see the various contributions in Sedmak (2010, 2012, 2013, 2014, 2015, 2016, 2017).

${ }^{22}$ Pechstein (2018, no. 1).

${ }^{23}$ Pechstein $(2018$, no. 8).

${ }^{24}$ Hermerén (2008, p. 375).

${ }^{25}$ Council conclusions on Common values and principles in European Union Health Systems, OJ 2006 C 146/1.
} 
Table 3.1 EU common values applied and further specified

\begin{tabular}{|c|c|c|c|c|}
\hline & Health & $\begin{array}{l}\text { Non-financial } \\
\text { reporting }\end{array}$ & Sports & Digitalization \\
\hline \multirow[t]{2}{*}{ Year } & \multirow[t]{2}{*}{2006} & \multirow[t]{2}{*}{2014} & - 2017 & \multirow[t]{2}{*}{2018} \\
\hline & & & - 2018 & \\
\hline \multirow[t]{3}{*}{ Legal status } & \multirow{3}{*}{$\begin{array}{l}\text { Soft-law } \\
\text { (conclusions of } \\
\text { health } \\
\text { ministers) }\end{array}$} & \multirow{3}{*}{$\begin{array}{l}\text { Binding } \\
\text { (amendment to } \\
\text { EU directive) }\end{array}$} & Soft law: & \multirow{3}{*}{$\begin{array}{l}\text { Soft-law } \\
\text { (advisory } \\
\text { opinion) }\end{array}$} \\
\hline & & & $\begin{array}{ll}\text { - } & \text { EP } \\
\text { resolution } \\
(2017)\end{array}$ & \\
\hline & & & $\begin{array}{l}\text { - Council } \\
\text { conclusions } \\
(2018)\end{array}$ & \\
\hline \multirow[t]{2}{*}{$\begin{array}{l}\text { Application or distinct } \\
\text { values }\end{array}$} & \multirow[t]{2}{*}{$\begin{array}{l}\text { (Mainly) } \\
\text { distinct values }\end{array}$} & \multirow[t]{2}{*}{$\begin{array}{l}\text { (Mainly) } \\
\text { application }\end{array}$} & $\begin{array}{l}\text { - Promotion } \\
\text { of EU } \\
\text { values, plus } \\
\text { distinct } \\
\text { values }\end{array}$ & \multirow[t]{2}{*}{$\begin{array}{l}\text { (Mainly) } \\
\text { application }\end{array}$} \\
\hline & & & \begin{tabular}{|l|l|} 
- & Mostly) \\
distinct \\
values
\end{tabular} & \\
\hline
\end{tabular}

is part of both the general and these specific values. ${ }^{26}$ For this example of health values, we can again identify the EU's motto of 'united in diversity', as these Council conclusions of 2006 emphasize "that the practical ways in which these values and principles become a reality in the health systems of the EU vary significantly between Member States, and will continue to do so". ${ }^{27}$ Unlike the general values, this document sheds further light on the content of these values. Equity, for instance, is determined in the sense that it "relates to equal access according to need, regardless of ethnicity, gender, age, social status or ability to pay". It is also worth mentioning that "[b]eneath [!] these overarching values, there is also a set of operating principles" 28 , which cover quality, safety, care that is based on evidence and ethics, patient involvement, redress, privacy and confidentiality.

From health, let us now turn to corporate social responsibility (CSR). Based on the EU rules on non-financial reporting ${ }^{29}$ for some large companies, the common good matrix, which lies at the heart of the Common Good Balance Sheet, is based on the values of "human dignity, solidarity and social justice, environmental sustainability, transparency and co-determination". ${ }^{30}$ This is an example of values having a direct

\footnotetext{
${ }^{26}$ On solidarity, see Prainsack and Buyx (2017).

${ }^{27}$ See Footnote 25. emphases added.

${ }^{28}$ See Footnote 27

${ }^{29}$ Directive 2014/95/EU amending Directive 2013/34/EU as regards disclosure of non-financial and diversity information by certain large undertakings and groups, OJ 2014 L 330/1.

${ }^{30}$ Economy for the common good: https://www.ecogood.org/en/common-good-balance-sheet/ common-good-matrix/.
} 
impact on (large) companies, where we find an application of some of the EU's values, adding other 'principles' we know from EU law, such as sustainability ${ }^{31}$ and transparency. ${ }^{32}$

An EP resolution on integrity, etc. in sports ${ }^{33}$ took both the approach of promoting the general EU values ("such as pluralism, tolerance, justice, equality and solidarity"), ${ }^{34}$ but also coined distinct values ("such as respect, friendship, tolerance and fair play" ${ }^{35}$; or "such as mutual respect, tolerance, compassion, leadership, equality of opportunity and the rule of law" ${ }^{36}$ ). Recently, the 2018 Council conclusions on promoting the common values of the EU through sport mainly refer to distinct values (printed in Italics), when they state that "sport can teach values such as fairness, teambuilding, democracy, tolerance, equality, discipline, inclusion, perseverance and respect that could help to promote and disseminate common values of the EU". ${ }^{37}$ The same is true, when they state that "[v]alues such as mutual respect, fair play, friendship, solidarity, tolerance and equality should be natural to all those involved in sport". ${ }^{38}$ As we can see, the majority of those values are not part of Art 2 TEU.

In digitalization, the Ethics Advisory Group established by the European Data Protection Supervisor has referred to dignity, freedom, autonomy, solidarity, equality, democracy, justice and truth, in order to leap from the EU's general common values to 'digital ethics' ${ }^{39}$ As we can see, the majority of values are those from Art 2 TEU (e.g. not comprising the rule of law, non-discrimination, tolerance), while also embracing autonomy, one of the principles from the 'principlism' of Beauchamp and Childress.

In terms of the legal status, no example except for the non-financial reporting directive, are legally binding (soft-law). Table 3.1 summarizes these four (non-exhaustive) examples of the EU's general common values in different specific fields.

These EU's general common values also have an external perspective. In its relations with the wider world, the EU "shall uphold and promote its values and interests and contribute to the protection of its citizens [..., contribute to peace, security, the sustainable development of the Earth, solidarity and mutual respect among peoples, free and fair trade, eradication of poverty and the protection of human rights" ${ }^{40}$

\footnotetext{
${ }^{31}$ Art 3(3) and (5) TEU, etc.

${ }^{32}$ Art 11 TEU, Art 15(3) TFEU, etc.

${ }^{33}$ EP resolution of 2 February 2017 on an integrated approach to Sport Policy: good governance, accessibility and integrity, OJ 2018 C 252/2 [EP resolution sport \& integrity].

${ }^{34}$ Ibid. pt. 45.

${ }^{35}$ Ibid. pt. 31.

${ }^{36}$ Ibid. pt. 44.

${ }^{37}$ Conclusions of the Council [etc.] on promoting the common values of the EU through sport, OJ 2018 C 196/23 (pt. 14).

${ }^{38}$ Ibid. pt. 17.

${ }^{39}$ Ethics Advisory Group (2018).

${ }^{40}$ Art 3(5) TEU; emphases added.
} 


\subsection{External Perspective: International Agreements, etc.}

After the constitutional perspective (EU primary law), let us now turn to the external ethical perspective. Following the hierarchy of EU law, ${ }^{41}$ the following chapter focuses on references to ethics and morality in international agreements (etc.), ${ }^{42}$ before we will then turn to the internal perspective (EU secondary law, etc.) in the next chapter.

The documents identified have been researched in the EU's EUR-Lex database, searching for the terms 'ethi*' and 'mora*' (both, in title and text), and in the two subcategories of 'international agreements' and in 'EFTA documents' ${ }^{43}$ This research comprises both 'international agreements' according to Art 216 TFEU, as well as 'association agreements' in the sense of Art 217 TFEU. Moreover, 'resolutions', for instance of a Joint (Parliamentary) Assembly, which have been documented in EUR-Lex, have also been taken into account. On the other hand, irrelevant terms have been excluded. ${ }^{44}$

\subsubsection{Status Quo of Ethics and Morality}

Often, EU law refers to ethics and/or morality in different sensitive fields. This is also the case for one prominent example of an international agreement, the 'Comprehensive Economic and Trade Agreement' (CETA) between Canada, of the one part, and the EU and its Member States, of the other part. ${ }^{45}$ In the heated debates, investment protection was one of the main issues. Hence, it is no surprise that the provision on the members of the multilateral investment tribunal is entitled 'ethics', emphasizing the importance of the independence of its members and the avoidance of both a direct or indirect conflict of interest. ${ }^{46}$ In addition, the 'Joint Interpretative Instrument' stresses that "[s]trict [!] ethical rules for these individuals have been set to ensure their independence and impartiality, the absence of conflict of interest, bias or appearance of bias". ${ }^{47}$

This example of CETA investment protection referring to ethics concerns a very sensitive issue, which is key for the trust of citizens in order to alleviate fears of big companies being able to 'buy justice'. In terms of determination of content, it is quite

\footnotetext{
${ }^{41}$ According to Art 216(2) TFEU, the agreements concluded by the Union are binding upon the EU institutions and on the MS.

${ }^{42}$ The following chapter is based on the research of Gruber (2015); the author would also like to thank Mr Weinkogl (also MCI) for checking updates to this research.

${ }^{43}$ On EFTA see infra at note 85 .

${ }^{44}$ See also Gruber (2015, pp. 19-22).

${ }^{45}$ OJ 2017 L11/1.

${ }^{46}$ Art 8.30 CETA.

${ }^{47}$ OJ 2017 L11/3 (4); emphases added. See also the Statement by the Commission and the Council on investment protection and the Investment Court System ('ICS'), on p. 20.
} 
clear what the reference to ethics should stand for (independence and avoidance of conflict of interest). Apart from investment protection, we can also find a reference to ethics in the context of the recognition of professional qualifications. ${ }^{48}$

References in CETA to 'morality' follow a common pattern, which we have already seen in EU primary law (Art 36 TFEU: 'public morality'), where the concept of 'public morals' is one of the exceptions (or: 'reasons of justification'), besides 'public order' and 'public safety', to name but a few.

Another example comprising several references to ethics is the Korea agreement. ${ }^{49}$ This agreement is also about trust based on ethics in a sensitive field. Here, 'ethical business practices' have to be set in place in order to avoid improper inducements by manufacturers and suppliers of pharmaceutical products or medical devices to health care professionals or institutions for the listing, purchasing or prescribing of pharmaceutical products and medical devices eligible for reimbursement under health care programmes. ${ }^{50}$

After those two representative examples of such international agreements referring to ethics, let us take a more detailed look at this issue and especially at the question of the determination of content (objective 1) of international agreements referring to ethics. Often we can find almost identical approaches in various agreements, as in some of the following examples referring to the Georgia agreement, the references could also have been indicated with regard to the Ukraine association agreement, ${ }^{51}$ to name but one.

- In the context of trade and customs legislation, we can find the situation, not of ethics being determined by reference to other notions such as avoidance of conflicts of interest, independence, etc., but on the contrary the opposite situation. The association agreement with Georgia refers to the 'Blueprint on Customs ethics' in order to determine "the highest standards of integrity" in this regard. ${ }^{52}$ In a similar way, the agreement with Indonesia refers to the 'World Tourism Organisation's Global Code of Ethics for Tourism' in order to "ensure balanced and sustainable development of tourism". ${ }^{53}$

- In the Georgia agreement, we can find one example, where the meaning of ethics can be traced in a systematic interpretation, when in the context of 'trade and investment promoting sustainable development', Art 231 refers to "voluntary sustainability assurance schemes such as fair and ethical trade schemes and eco-labels".

\footnotetext{
${ }^{48}$ OJ 2017 L11/306.

${ }^{49}$ Free trade Agreement between the EU and its MS, and the Republic of Korea, OJ 2011 L 127/6 [Agreement Korea].

${ }^{50}$ Ibid. Annex 2-D, Art 4(1).

${ }^{51}$ Association Agreement between the EU and the European Atomic Energy Community [EAEC] and their MS, and Ukraine, OJ 2014 L 161/3, as amended by OJ 2018 L 188/17 [Agreement Ukraine].

${ }^{52}$ Association Agreement between the EU and the EAEC and their MS, and Georgia, OJ 2014 L 261/4, as amended by OJ 2018 L 140/107 [Agreement Georgia], Art 67(2)(e); emphasis added.

${ }^{53}$ Framework Agreement on comprehensive partnership and cooperation between the European Community and its MS, and Indonesia, OJ 2014 L 125/17, Art 17(1).
} 
Similar examples can be found in the context of tourism ("promote ethical standards in tourism by introducing a certified European Fair Trade Tourism label"). ${ }^{54}$

- Another common field of 'ethicalization' are references to 'professional ethics' both in the private, as well as in the public field. Such rules can even apply after leaving the job. ${ }^{55}$

- For lawyers providing legal services in respect of public international law and foreign law, the Georgia agreement refers to "compliance with local codes of ethics". 56 This approach makes sense, if the legal rules in this area are also located at national level.

- Professional ethics in the public field can be found in the Moldova agreement. ${ }^{57}$ This agreement foresees rules on cooperation, with the aim of fostering efficient and accountable public administration in Moldova, and to support the implementation of the rule of law. This cooperation shall, amongst others, also cover "the promotion of ethical values in the civil service". ${ }^{58}$ It is interesting to see the link between ethics and values, although the detailed content remains somehow vague.

- In another private field, the agreement with Central America states that cooperation on microcredit and microfinance shall also address the "exchange of experiences and expertise in the area of ethical banking". ${ }^{9}$ The same statement with regard to the determination of ethics applies here.

- Although training is an important element for ethical behaviour, ${ }^{60}$ the following example is completely undetermined. This agreement states that elements of a training programme for port State inspectors should include, amongst others, "[E]thics". ${ }^{61}$ Maybe this lacking determination is less of a problem, as 'ethics' here can be read in terms of the title of a subject of this training programme.

- In the field of healthcare, we have already seen the example of the Korea agreement, referring to ethical business practices of improper inducements by manufacturers and suppliers of pharmaceutical products or medical devices to health care professionals or institutions. ${ }^{62}$

\footnotetext{
${ }^{54}$ Resolution on the impact of tourism on the development of ACP countries, OJ 2006 C 330/15 [Resolution tourism], pt. 21.

${ }^{55}$ Decision No 2/92 of the ACP-EEC Committee of Ambassadors of 22 December 1992 laying down the Staff Regulations of the Technical Centre for Agricultural and Rural Cooperation under the Fourth ACP-EEC Convention, OJ 1993 L 53/33, Art 16.

${ }^{56}$ Ibid. Annex XIV-B; emphasis added.

${ }^{57}$ Association Agreement between the EU and the EAEC and their MS, and Moldova, OJ 2014 L 260/4, as amended by OJ 2018 L 176/21.

${ }^{58}$ Ibid. Art 22(e); emphasis added.

${ }^{59}$ Agreement establishing an Association between the EU and its MS, and Central America, OJ 2012 L 346/3, as amended by OJ 2015 L 196/59, Art 71.

${ }^{60}$ Frischhut (2015, p. 572).

${ }^{61}$ Agreement on Port State Measures to Prevent, Deter and Eliminate Illegal, Unreported and Unregulated Fishing, OJ 2011 L 191/3, Annex E.

${ }^{62}$ Supra, note 50.
} 
- Another provision of the same Annex on pharmaceutical products and medical devices confirms the shared principles of the contracting parties with regard to "ethical practices by manufacturers and suppliers of pharmaceutical products and medical devices and by health care providers on a global basis in order to achieve open, transparent, accountable and non-discriminatory health care decision-making". ${ }^{63}$ As the $\operatorname{telos}^{64}$ is clearly stated, we have a strong guidance towards the determination of the meaning of ethics in this regard. This example is reminiscent of consequentialism ('in order to'), however, at the same time exhibits some elements of principlism ${ }^{65}$ (transparency, non-discrimination, etc.).

- Another example in cross-border healthcare deals with a kind of 'circumvention tourism'. ${ }^{66}$ This resolution "[c]alls on all States to ensure the ethics of transplantation by adopting measures to eliminate 'transplant tourism"" ${ }^{67}$ Here, too, we have a strong guidance with regard to the determination of the content of ethics, as the telos is clearly stated.

- In another field, which we can entitle with 'ethics and society', we find a reference to "the ethical, cultural and social values of the society" to which children belong and which shall not prejudice the right of the child to a loving family. ${ }^{68}$ Although ethics is not determined in this document itself, we can read it as a reference to the national or regional level of the relevant society.

After ethics, let us now turn to references to morality. The introductory example of CETA is representative in the sense that in the majority of cases, "public morality' 69 is used as an exception clause. ${ }^{70}$ Besides public security or public order, "public morals' can be such a reason of justification ('exception'), provided that such measures are not applied in a manner which would constitute a means of "arbitrary or unjustifiable discrimination between countries where like conditions prevail, or a disguised restriction on establishment or cross-border supply of services". ${ }^{71}$ This is an approach, which we already know from inside of the internal market.

A slightly different version of an exception clause can be found in the Ukraine Agreement, where one of the grounds for refusal or invalidity of a trademark registration are trademarks, which are contrary to 'public policy' or "to accepted principles

\footnotetext{
${ }^{63}$ OJ 2011 L 127/1154, Annex 2-D, Art 1(e); emphases added.

${ }^{64}$ On the replacement of the term 'teleological' by ' consequentialist', see Louden (2012, p. 503).

${ }^{65}$ The notion of 'principlism' can refer to the above-mentioned four principle-approach of Beauchamp and Childress. However, it can also be seen in a broader sense, referring to any ethical approach, basing its deliberations on principles. The author would like to thank Göran Hermerén (Lund University | 2002-2011 EGE president/chairperson) for valuable feedback in this regard.

${ }^{66}$ Cohen (2012).

${ }^{67}$ Resolution tourism, pt. 33.

${ }^{68}$ Resolution on children's rights and child soldiers in particular, OJ 2004 C 26/17, recital D.

${ }^{69}$ E.g. Trade Agreement between the EU and its Member States, and Colombia and Peru, OJ 2012 L 354/3, as amended by OJ 2018 L 1/1, Art 106(1)(a).

${ }^{70}$ Gruber (2015, p. 28).

${ }^{71}$ Agreement Georgia, Art 134(2)(a); emphases added.
} 
of morality". ${ }^{72}$ While this concept is undetermined, a similar provision on patents (protection of biotechnological inventions) is more precise, as it states examples of what is considered un-patentable: processes for cloning human beings, or modifying their germ line genetic identity, as well as uses of human embryos for industrial or commercial purposes. ${ }^{73}$

In the field of development aid, we find examples of morality used as an argument supporting a certain position. A resolution on climate change states that industrialised countries "have a historical responsibility for climate change and are morally obliged to assist ACP countries". ${ }^{74}$ Another one notes the "moral and sovereign rights of affected Southern African states to accept or reject GMOs coming as food aid", 75 as well as the "eradication of poverty to be a moral and political imperative". ${ }^{76}$ This phenomenon causes no major challenges, if a legal provision 'only' refers to moral (or ethical) considerations as a supporting argument. ${ }^{77}$

This is more difficult with the following example, as it is not quite clear, what is meant by the "moral, political and economic support [that] should be offered to the Burundian people". ${ }^{78}$ How does a moral support look like, is there a right to moral support, etc.?

- An interesting example can be found in the following resolution on embargoes: "Points out that, whilst the overt reason for imposing sanctions is normally to bring about a change of regime in a particular country, or at least a major change in the policy of that country's government, their imposition may also serve simply as an expression of moral condemnation". ${ }^{79}$ While besides other hard-facts morality also seems to be important, we can see this as a minimum approach ('at least' moral support).

- The wording "every child has a right to a standard of living adequate for the child's physical, mental, spiritual, moral and social development" ${ }^{\prime 80}$ is reminiscent of Art 32 CFR, which addresses the "physical, mental, moral or social development" of young people at work.

- The following example concerning the appointment of arbitrators reminds us of the members of the multilateral investment tribunal in CETA: "appointment of an

\footnotetext{
${ }^{72}$ Art 193(2)(f); for a similar provision on designs see Art 217(5).

${ }^{73}$ Art 221(5); see also (d) on animals. On the similarity with an EU directive (note 113), see infra Sect. 4.1.

${ }^{74}$ Resolution on the social and environmental consequences of climate change in the ACP countries, OJ 2009 C 221/31, recital O; emphases added.

${ }^{75}$ Resolution on the situation in Southern Africa, OJ 2003 C 231/53, recital F.

${ }^{76}$ Resolution on the future of ACP-EU relations, OJ 1999 C 271/35, pt. 4.

${ }^{77}$ Frischhut (2015, p. 561).

${ }^{78}$ Resolution on support for the peace process in Burundi, OJ 1999 C 271/49, recital B; emphasis added.

${ }^{79}$ Resolution on the impact of sanctions and, in particular, of embargoes on the people of the countries on which such measures are imposed, OJ 2002 C 78/32 [Resolution embargoes], pt. 2.

${ }^{80}$ Convention on the International Recovery of Child Support and Other Forms of Family Maintenance, OJ 2011 L 192/51, recital 5(2).
} 
independent and impartial arbitrator of a nationality other than the nationalities of the parties, and of high moral standing." 81 The content of this moral standing remains undetermined.

- The same applies for the last example in this regard: "The salary and social contributions of observers shall be borne by the competent authorities of the Gabonese Republic. Captains shall do everything in their power to ensure the physical and moral safety of observers carrying out their duties." 82

Finally, we do not only find examples relating to human beings, in the context of animal transport, the preamble of this Convention holds that "every person has a moral obligation to respect all animals and to have due consideration for their capacity for suffering", 83 and another one with a similar wording referring to "their capacity for suffering and memory". ${ }^{84}$ Hence, two references to moral obligations, which can be seen as supporting arguments.

After international agreements, let us now turn to documents of the 'European Free Trade Area' (EFTA), which are displayed here in a separate way due to three reasons. First, because of the significance of this agreement, second, because they are also separately documented in the EUR-Lex database, and finally, because they occur in a different context. EFTA comprises Norway, Iceland, Liechtenstein and Switzerland, where all of these countries, except for Switzerland, are linked to the EU via the European Economic Area (EEA). ${ }^{85}$

There are two examples of EFTA documents referring to ethics, both from the EFTA Surveillance Authority (ESA), which is the equivalent to the EC in terms of monitoring and enforcing the relevant rules. In the context of the financial crisis, a global reduction in liquidity, and various other complex reasons led to the collapse of the three main Islandic banks. An essential part of the Icelandic financial sector "was the restructuring of household and corporate debt", which was qualified to be "a complex and sensitive issue with a number of financial, economic and ethical considerations". ${ }^{86}$ Some of the "most relevant changes" addressed in terms of restructuring aid granted to the Landsbankinn banks was "revised risk manage-

\footnotetext{
${ }^{81}$ Decision No 3/90 of the ACP-EEC Council of Ministers of 29 March 1990 adopting the general regulations, general conditions and procedural rules on conciliation and arbitration for works, supply and service contracts financed by the European Development Fund (EDF) and concerning their application, OJ 1990 L 382/1, Annex V, Art 10(3)(a).

${ }^{82}$ Protocol setting out the fishing opportunities and the financial contribution provided for by the Agreement between the European Community and the Gabonese Republic on fishing off the coast of Gabon for the period 3 December 2001 to 2 December 2005, OJ 2002 L 73/19, Annex, pt. 7.

${ }^{83}$ European Convention for the Protection of Animals during International Transport (revised), OJ 2004 L 241/22 [Convention animal transport], recital 2; emphasis added.

${ }^{84}$ European Convention for the protection of vertebrate animals used for experimental and other scientific purposes, OJ 1999 L 222/31, as amended by OJ 2003 L 198/11 [Convention animal experiments], recital 2.

${ }^{85}$ Agreement on the European Economic Area, OJ 1994 L1/3, as amended by OJ 2016 L 141/3. ${ }^{86}$ ESA Decision No 291/12/COL of 11 July 2012 on restructuring aid to Arion Bank (Iceland), OJ 2014 L 144/169, recital 123; emphasis added.
} 
ment and a greater significance of corporate responsibility and compliance with high ethical standards". 87

What we can see here is another example of referring to ethics in a sensitive field. The first example exhibits a general awareness for ethics, ${ }^{88}$ while the second is not determined regarding its content. How should those standards look like, where could they be found? Such ethical rules should be further determined, especially in the banking sector.

Both ESA decisions also address the issue of 'moral hazard', which is a term of microeconomics. "In general, moral hazard occurs when a party whose actions are unobserved affects the probability or magnitude of a payment". ${ }^{89}$ This can occur in case "of workers who perform below their capabilities when employers cannot monitor their behavior ('job shirking')", 90 or in case of banks shifting risk to the general tax-paying public. Both decisions address moral hazard in the context of burden sharing in the sense that "aid should be limited to the minimum necessary and an appropriate own contribution to restructuring costs should be provided by the aid beneficiary". ${ }^{91}$ These examples of referring to a non-legal term are less of a problem. First, we deal with a reference to a determined concept (here not of practical philosophy, but of economics), and the consequences are clearly stated. Hence, we could qualify this reference as a supporting argument, as we have already seen. ${ }^{92}$

In terms of morality, we can find an example of referring to moral obligations in a situation, where no legal obligation exists. In the discussion of adjusting the EEA agreement in terms of higher contributions in the context of the EU enlargement, one argument used was “the EEA EFTA States' obligation to provide (moral) support in connection with the enlargement of the EU". This was stated, because under the EEA Agreement, "the EU has no legal entitlement to demand a sharp increase in the previous level of payments". 93

\subsubsection{Conclusion}

As of 1993, we can trace the first references to ethics in international agreements, with the majority of relevant documents since the turn of the millennium. ${ }^{94}$ This

\footnotetext{
${ }^{87}$ ESA Decision No 290/12/COL of 11 July 2012 on restructuring aid granted to Landsbankinn (Iceland), OJ 2014 L 144/121, recital 104; emphasis added.

${ }^{88}$ Gruber (2015, p. 40).

${ }^{89}$ Pindyck and Rubinfeld (2018, p. 658); no emphasis added.

${ }^{90}$ Pindyck and Rubinfeld (2018, p. 658).

${ }^{91}$ ESA Decision No 291/12/COL, recital 204; ESA Decision No 290/12/COL, recital 207; et passim.

${ }^{92}$ Supra note 77.

${ }^{93}$ Resolution on the "Enlargement of the European Economic Area (EEA)—institutional and legal issues", OJ 2003 C 308/16, pt. 4.5.

${ }^{94}$ Gruber (2015, pp. 22-23).
} 
roughly corresponds with the general 'ethicalization' in terms of the founding of ethics advisory bodies at EU level in 1991 and 1997 respectively. ${ }^{95}$

We have seen references to ethics in several sensitive fields, such as investment tribunals, influence of the pharma industry on doctors, etc., or the supporting of private banks with taxpayers' money. What these examples have in common is the fact that ethics is always a means of strengthening citizens' trust in these areas.

Often we have seen similar approaches in different agreements, as well as a link between concepts such as integrity and ethics. The key question, which is the determination of content of both ethics and morality (i.e. objective 1) has to be answered in a differentiated way: sometimes, it was possible to trace the meaning of these references to ethics and morality, but at times, this was not the case. In some of the numerous references in the context of professional ethics, the task of determining the content was one of the national level, as this level was also in charge of the legal perspective. The notion of morality has mainly been used as an exception clause, besides self-standing notions such as 'moral hazard'. The beneficiaries of ethical behaviour have mainly been humans, but some examples also covered animals. Some of these documents also referred to related concepts such as values. ${ }^{96}$ This is true for CETA, which "reflects the strength and depth of the EU-Canada relationship, as well as the fundamental values that we cherish". ${ }^{97}$ No references to ethics or morality can be found in the recent EU Japan agreement published in July $2018 .^{98}$

\subsection{Internal Law Making Perspective}

\subsubsection{A 'Gouvernement Des Juges'?}

EU law also comprises case-law and the CJEU case-law has played a paramount role in shaping the EU acquis. Therefore, let us now turn to ethics and morality in caselaw and analyse the CJEU's approach in this field. In EU integration in general, the CJEU has often been criticized for its pro-active role. ${ }^{99}$ As already mentioned, this chapter shall answer the question, if we can observe a 'gouvernement des juges', or if the CJEU rather takes a more reluctant approach, a so-called 'judicial self-restraint' (i.e. objective 3 )?

\footnotetext{
${ }^{95}$ See infra Sect. 4.2.1.

${ }^{96}$ For further details see Gruber (2015, pp. 34-37).

${ }^{97}$ CETA Joint Interpretative Instrument, recital 1(c).

${ }^{98}$ Strategic Partnership Agreement between the EU and its MS, and Japan, OJ 2018 L 216/4.

${ }^{99}$ On this issue see Dawson et al. (2013), Horsley (2013), Lienbacher (2013), Martinsen (2015).
} 


\subsubsection{The CJEU's Judicial Self-restraint}

Analysing the case-law of the CJEU, one has to be aware of cases where the judgment merely quotes EU legislation (as this will be covered separately ${ }^{100}$ ), international or national law. In addition, ethics and morality used as arguments of the parties of a case (EC, other EU institutions, or MS) have to be seen in a different light, the same applies for questions of a national court in a preliminary ruling procedure. Finally, one has to separate arguments of an Advocate General, and the binding judgment of the Court of Justice.

EU law affects almost every aspect of national law, thus also some very sensitive areas. As the Court has held, there are areas "in which there are significant moral, religious and cultural differences between the Member States. In the absence of [EU] harmonisation in the field, it is for each Member State to determine in those areas, in accordance with its own scale of values, what is required in order to ensure that the interests in question are protected". ${ }^{101}$ This is the case in the following fields: various games of chance, ${ }^{102}$ the import of "articles having an indecent or obscene character", ${ }^{103}$ protection of children from immoral media, ${ }^{104}$ prostitution, ${ }^{105}$ or abortion. ${ }^{106}$

We have already seen the notion of 'public morality', as one of the reasons of justification in the context of the fundamental freedoms of the internal market, where a similar approach was taken in international agreements. Interpreting this reason of justification, the Court held that "in principle it is for each Member State to determine in accordance with its own scale of values and in the form selected by it the requirements of public morality in its territory" ${ }^{107}$ Hence, it is not the EU to determine this notion, nor a majority of MS, but each single MS. Reference is also made to the national values, although one should take into account that this statement (1986) was given roughly 20 years before the Lisbon Treaty inserted Art 2 TEU on the common values. ${ }^{108}$ The limitation stated in this case was the one of double morality', where goods legal in the home country cannot be qualified as obscene, if imported from another MS. ${ }^{109}$

\footnotetext{
${ }^{100}$ See infra Sect. 3.3.3.

${ }^{101}$ CJEU judgment of 8 September 2009, Liga Portuguesa, C-42/07, EU:C:2009:519, para 57; emphases added.

${ }^{102}$ Ibid (games of chance via the internet); CJEU judgment of 24 March 1994, Schindler, C-275/92, EU:C:1994:119, para 32 (lotteries); CJEU judgment of 6 March 2007, Placanica, joined cases C-338/04, C-359/04 and C-360/04, EU:C:2007:133, para 47 (betting and gaming).

${ }^{103}$ CJEU judgment of 14 December 1979, Henn and Darby, C-34/79, EU:C:1979:295, para 15; CJEU Conegate, 121/85, para 14; emphases added.

${ }^{104}$ CJEU judgment of 14 February 2008, Dynamic Medien, C-244/06, EU:C:2008:85, para 44.

${ }^{105}$ CJEU judgment of 20 November 2001, Jany, C-268/99, EU:C:2001:616, para 56.

${ }^{106}$ CJEU SPUC, C-159/90, para 20.

${ }^{107}$ CJEU Conegate, 121/85, para 14; emphases added.

${ }^{108}$ On the "ethical values in sport", see CJEU judgment of 18 July 2006, Meca-Medina, C-519/04 P, EU:C:2006:492, para 43.

${ }^{109}$ CJEU Conegate, 121/85, para 20.
} 
'Ethics' was an issue for instance in an Austrian case on the protection of pregnant workers against dismissal from work. ${ }^{110}$ The question was on the beginning of pregnancy in case of in vitro fertilisation (IVF): either already at the time of fertilization of her ova by her partner's sperm cells, or at the time of transfer into her uterus. Before providing an answer on the details of this case, the Court gave a very important general statement:

artificial fertilisation and viable cells treatment is a very sensitive social issue in many Member States, marked by their multiple traditions and value systems, the Court is not called upon, by the present order for reference, to broach questions of a medical or ethical nature, but must restrict itself to a legal interpretation of the relevant provisions of [EU law]. ${ }^{111}$

At the time of this judgment, the Lisbon Treaty had already been signed (2007), although not yet entered into force (2009). Still, the Court referred to the "multiple traditions and value systems". This Grand Chamber judgment clearly demonstrates the Court's judicial self-restraint, comprising various dimensions: a vertical one, whereas these questions have to be determined at a national level, as well as a horizontal one, according to which it is for the legislature and not for the courts, to decide on these "sensitive social issue[s]". As the Court has held in other cases concerning 'morality', "[e]ven if the morality of lotteries is at least questionable, it is not for the Court to substitute its assessment for that of the legislatures of the Member States". ${ }^{112}$ Even if the Court, in the following, decides this IVF case solely by interpreting the relevant provisions of EU law (i.e. beginning of pregnancy only as of transfer into uterus), in the end this legal interpretation of legal norms will have an indirect impact on the ethical nature of this topic. Moreover, although it is for the MS to take these decisions, the legal interpretation takes place at EU level. Based on this analysis, it is also not really a necessity for the CJEU to determine the content of the concept of 'ethics', as this perspective has been clearly excluded for the procedure of solving this case.

Three years later, the Court (again, Grand Chamber) had to decide another case in the field of bioethics, namely on the patentability of neural precursor cells and the processes for their production from embryonic stem cells. This case was about the Directive on biotechnological inventions, which, amongst others, excludes the patentability of "uses of human embryos for industrial or commercial purposes". ${ }^{113}$ The key challenge, thus, centred on the interpretation of the notion of 'human embryo'. The Court confirmed its statement in Mayr, not to decide questions of ethical nature in very sensitive fields, which are marked by MS's "multiple traditions and value systems",

\footnotetext{
${ }^{110}$ On additional challenges in case of cross-border reproductive care, see Frischhut (2017).

${ }^{111}$ CJEU judgment of 26 February 2008, Mayr, C-506/06, EU:C:2008:119, para 38; emphases added.

${ }^{112}$ CJEU SPUC, C-159/90, para 20; CJEU Schindler, C-275/92, para 32.

${ }^{113}$ Directive 98/44/EC of 6 July 1998 on the legal protection of biotechnological inventions, OJ 1998 L 213/13 [Directive Biotech], Art 6(2)(c). On this directive, see also infra Sect. 3.3.3.1.
} 
such as the definition of human embryo. ${ }^{114}$ However, it took a different approach, as this statement would suggest. The Court lifted the interpretation of this notion form the MS level at EU level, when stating that the notion of 'human embryo' is "an autonomous concept of European Union law which must be interpreted in a uniform manner throughout the territory of the Union". ${ }^{115}$ While there are good reasons that notions, which are decisive for the internal market are defined at EU level, ${ }^{116}$ a consistent application of the 'multiple value systems' approach should have led to a definition at national level, only constrained by the limitation of 'double morality'. 117

Based on the concept of 'human dignity', which was mentioned in the Directive as a reason to exclude patentability, ${ }^{118}$ the Court held "that the concept of 'human embryo' within the meaning of Article 6(2)(c) of the Directive must be understood in a wide sense" 119 and came to the following solution for fertilised and non-fertilised ova.

Accordingly, any human ovum must, as soon as fertilised, be regarded as a 'human embryo' within the meaning and for the purposes of the application of Article 6(2)(c) of the Directive, since that fertilisation is such as to commence the process of development of a human being. ${ }^{120}$

That classification must also apply to a non-fertilised human ovum into which the cell nucleus from a mature human cell has been transplanted and a non-fertilised human ovum whose division and further development have been stimulated by parthenogenesis. Although those organisms have not, strictly speaking, been the object of fertilisation, due to the effect of the technique used to obtain them they are, as is apparent from the written observations presented to the Court, capable of commencing the process of development of a human being just as an embryo created by fertilisation of an ovum can do so. ${ }^{121}$

It is important to stress, from where the Court got this 'natural science' related information. Here, in Brüstle, the Court relied on information presented by the parties of this case, in $M a y r^{122}$ the relevant information was provided by the Commission.

Three years later, in another Grand Chamber judgment, the Court partly had to revoke the approach it took in Brüstle, when interpreting the same legal provision. This case was about unfertilised human ovum (second quotation mentioned above) whose division and development to a certain stage have been stimulated by parthenogenesis. Although in this case the Court itself did not refer to the terms ethics or morality, this judgment is highly relevant to our issue. The Court emphasized that

${ }^{114}$ CJEU judgment of 18 October 2011, Brüstle, C-34/10, EU:C:2011:669, para 30; referring to CJEU Mayr, C-506/06, para 38.

${ }^{115}$ CJEU Brüstle, C-34/10, para 26; emphases added.

${ }^{116}$ CJEU Brüstle, C-34/10, para 27.

${ }^{117}$ On proportionality see infra at note 135 .

${ }^{118}$ Directive Biotech, recitals 16 and 38.

${ }^{119}$ CJEU Brüstle, C-34/10, para 34; emphasis added.

${ }^{120} \mathrm{CJEU}$ Brüstle, C-34/10, para 35; emphases added.

${ }^{121}$ CJEU Brüstle, C-34/10, para 36; emphases added.

${ }^{122}$ CJEU Mayr, C-506/06, para 30. 
the legal solution in Brïstle had been based on "the written observations presented to the Court". 123

However, in the present case, the referring [N.B. national] court [...] stated in essence that, according to current scientific knowledge, a human parthenote, due to the effect of the technique used to obtain it, is not as such capable of commencing the process of development which leads to a human being. That assessment is shared by all of the interested parties who submitted written observations to the Court. ${ }^{124}$

In the following, the Court did not take the final decision itself, but left it to the national court "to determine whether or not, in the light of knowledge which is sufficiently tried and tested by international medical science [...], human parthenotes, such as those which are the subject of the applications for registration in the case in the main proceedings, have the inherent capacity of developing into a human being". ${ }^{25}$

What we can take away from this case is the fact that the Court's approach in Brüstle, to shift the solution of a "very sensitive" issue at EU level, was a "flash in the pan'. It is difficult to verify or falsify the statement that the CJEU's interpretation of human dignity in Brüstle was "motivated by (covert) religious motives". ${ }^{126}$ However, we can clearly state that nowadays it is more likely that the CJEU would decide a case such as Brüstle in a more reluctant way, that is to say, not to lift such interpretations of key terms (such as 'human embryo') to EU level. The Court also made clear that its statements are "limited to the patentability of biotechnological inventions". ${ }^{127}$ In other words, the CJEU did not want to decide the issue of the beginning of human life in general. This sectoral approach is also important insofar as otherwise we would have a contradiction between Mayr (transfer into uterus) on the one hand, and Brüstle (human embryo, as soon as fertilised) as well as ISC ("capacity to develop into a human being" 128 , on the other.

Another example of the Court's more reluctant approach in a sensitive field is 'surrogacy', a phenomenon, which, according to the EP, "undermines the human dignity of the woman since her body and its reproductive functions are used as a commodity". ${ }^{129,130}$ In two judgments, both given nine month before the ISC case, the Court had to decide technical questions of non-discrimination based on gender ${ }^{131}$ and disability. ${ }^{132}$ Although surrogacy can easily be qualified as a "very sensitive social

\footnotetext{
${ }^{123}$ CJEU judgment of 18 December 2014, International Stem Cell [ISC], C-364/13, EU:C:2014:2451, paras 31-32.

${ }^{124}$ CJEU ISC, C-364/13, para 33; emphases added.

${ }^{125}$ CJEU ISC, C-364/13, para 36; emphases added.

${ }^{126}$ Plomer $(2018,36)$.

${ }^{127}$ CJEU ISC, C-364/13, para 22.

${ }^{128}$ CJEU ISC, C-364/13, para 31.

${ }^{129} \mathrm{EP}$ annual report on human rights and democracy in the world 2014 and the EU policy on the matter, P8_TA(2015)0470 [EP report human rights], para 114; emphases added.

${ }^{130}$ On the topic of commodification, see Sandel (2012).

${ }^{131}$ CJEU judgment of 18 March 2014, D, C-167/12, EU:C:2014:169.

${ }^{132}$ CJEU judgment of 18 March 2014, Z, C-363/12, EU:C:2014:159.
} 
issue" as stated in Mayr ${ }^{133}$ and Brüstle, ${ }^{134}$ the Court (again, Grand Chamber) neither referred to ethics nor morality, and solved this case at a legal level in a very technical way. One explanation could be that the relevant provisions of EU law did not refer to these terms of 'ethics' or 'morality', which is why the Court saw no necessity to 'leave the legal turf'.

After these examples related to different EU directives, let us turn back to the fundamental freedoms. Here we have seen the Court's reluctant approach, leaving more discretion to the MS, which corresponds with the 'post-Brüstle approach'. The key limitation we have seen there was a prohibition of 'double morality'. ${ }^{135}$ Apart from this, the CJEU has developed another very acceptable solution to deal with ethically sensitive issues, which is a 'more generous' proportionality ${ }^{136}$ review. This has been qualified as a "procedural" review by de Witte in his seminal paper "Sex, drugs \& EU law", ${ }^{137}$ or as a "minimal proportionality control" by Hatzopoulos. ${ }^{138}$ This can be seen as a 'golden mean' between either deciding these questions at national level in terms of diversity of moral and ethical choices (argument from selfdetermination ${ }^{139}$ ), and the decision of such issues at EU level by "the transnational judiciary" (argument from containment ${ }^{140}$ ). This means that the CJEU intervenes less substantively in the national regulation by means of the proportionality test, or as de Witte puts it:

It is argued that a procedural proportionality test that respects the substance of national moral and ethical choices, and that instead focuses on teasing out discriminatory or protectionist biases, must only assess the normative coherence of national policies, the consistent application of sanctions, and legislative transparency. ${ }^{141}$

The CJEC would therefore not require a Member State to follow the approach of another Member State. As long as the Member State concerned does not act in contradictory ways within its own legal system, the CJEC will not 'interfere'. This approach also entails the prohibition of 'double morality', as mentioned above.

In this context, the CJEU has also made an important clarification in the famous Omega case. The question centred on the number of MS that have to adopt a certain position based on ethical or moral grounds. In an earlier judgment on gambling, the Court has held as follows:

First of all, it is not possible to disregard the moral, religious or cultural aspects of lotteries, like other types of gambling, in all the Member States. The general tendency of the Member

\footnotetext{
${ }^{133}$ CJEU Mayr, C-506/06, para 38.

${ }^{134}$ CJEU Brüstle, C-34/10, para 30.

${ }^{135}$ Supra at note 109.

${ }^{136}$ On proportionality, see also Hermerén (2012).

${ }^{137}$ de Witte (2013, p. 1573).

${ }^{138}$ Hatzopoulos (2012, p. 159).

${ }^{139}$ de Witte (2013, p. 1551).

${ }^{140}$ de Witte (2013, p. 1552).

${ }^{141}$ de Witte (2013, p. 1573); no emphasis added.
} 
States is to restrict, or even prohibit, the practice of gambling and to prevent it from being a source of private profit. [... $]^{142}$

The necessary number of MS having to share a similar view was clarified as follows:

It is not indispensable in that respect for the restrictive measure issued by the authorities of a Member State to correspond to a conception shared by all Member States as regards the precise way in which the fundamental right or legitimate interest in question is to be protected. Although, in paragraph 60 of Schindler [N.B. see supra], the Court referred to moral, religious or cultural considerations which lead all Member States to make the organisation of lotteries and other games with money subject to restrictions, it was not its intention, by mentioning that common conception, to formulate a general criterion for assessing the proportionality of any national measure which restricts the exercise of an economic activity. ${ }^{143}$

Omega was not only an important case in terms of the extent of a consensus between MS, it can also be seen as a landmark case in terms of addressing values, ${ }^{144}$ three years before the signing of the Lisbon Treaty. This case was about the possibility to restrict the fundamental freedoms based on "a fundamental value enshrined in the national [i.e. German] constitution, namely human dignity". ${ }^{145}$ The Court allowed this national value, now an EU value, to enter the fundamental freedoms via the notion of 'public order', despite the high requirements in this context: first, 'public policy' "must be interpreted strictly" and, second, there has to be a "genuine and sufficiently serious threat to a fundamental interest of society". ${ }^{146}$ The strong content-related link between 'public policy' as a legal reason of justification and morality also becomes obvious, when the Court states that "the concept of public policy may vary from one country to another and from one era to another" ${ }^{147}$; thus, also the regional and evolutionary character, we have already seen for 'public morality'.

Another sensitive area is genetically modified organisms ('GMOs'). In this context, a directive emphasizes the importance of "ethical principles recognised in a Member State", which allows them to "take into consideration ethical aspects when GMOs are deliberately released or placed on the market as or in products". ${ }^{48}$ This might have inspired Poland to argue with ethical principles for defending noncompliance with this Directive, precisely the argument that "the adoption of the contested national provisions was inspired by the Christian and Humanist ethical

\footnotetext{
${ }^{142}$ CJEU Schindler, C-275/92, para 60; emphases added.

${ }^{143}$ CJEU judgment of 14 October 2004, Omega, C-36/02, EU:C:2004:614, para 37; emphases added.

${ }^{144}$ This book is based on a more narrow understanding of values (see Sect. 3.1.3), than the broad approach (of five categories) by Saurugger and Terpan (2018) (internal market, social values, human rights, EU governance, as well as fostering European integration and protecting the autonomy of European legal order).

${ }^{145}$ CJEU Omega, C-36/02, para 32; emphases added.

${ }^{146}$ CJEU Omega, C-36/02, paras 28 and 30.

${ }^{147}$ CJEU Omega, C-36/02, paras 31.

${ }^{148}$ Directive 2001/18/EC of 12 March 2001 on the deliberate release into the environment of genetically modified organisms [...], OJ 2001 L 106/1, as amended by OJ 2018 L 67/30 [Directive GMOs], recital 9.
} 
principles adhered to by the majority of the Polish people". ${ }^{149}$ In this regard, Poland put forward the following arguments:

a Christian conception of life which is opposed to the manipulation and transformation of living organisms created by God into material objects which are the subject of intellectual property rights; a Christian and Humanist conception of progress and development which urges respect for creation and a quest for harmony between Man and Nature; and, lastly, Christian and Humanist social principles, the reduction of living organisms to the level of products for purely commercial ends being likely, inter alia, to undermine the foundations of society. ${ }^{150}$

This case would have allowed the CJEU to broach intriguing questions of the relationship of EU law and ethics. However, the Court did not enter into a substantive analysis. By stating that Poland, "upon which the burden of proof lies in such a case, has failed, in any event, to establish that the true purpose of the contested national provisions was in fact to pursue the religious and ethical objectives relied upon", ${ }^{151}$ it is consequently "not necessary to rule on the question whether - and, if so, to what extent and under which possible circumstances - the Member States retain an option to rely on ethical or religious arguments in order to justify the adoption of internal measures which [...] derogate from [EU law]". ${ }^{152}$ While it is not surprising that the Court did not allow a MS to deviate from legal obligations of an EU Directive, this statement at least leaves open the possibility of a MS, which is able to comply with this burden of proof, to rely on ethical grounds. This case is also interesting because it does not only address the relationship of EU law and ethics, but also of ethics and religion, precisely, one religion (Christianity), and of humanism.

It is also worth mentioning that Poland has positioned ethics as an argument at different levels, in order to defend its position. Poland referred to both the Polish society which "attaches great importance to Christian and Roman Catholic values", as well as to the members of the Polish parliament. ${ }^{153}$ It is no surprise, that the Court clearly rejected this possibility by stating "a Member State cannot rely in that manner on the views of a section of public opinion in order unilaterally to challenge a harmonising measure adopted by the [EU] institutions". ${ }^{154}$

\subsubsection{Conclusion}

Based on the analysis of this case-law the above-mentioned question can clearly be addressed in the sense of a judicial self-restraint. This is true both with regard

\footnotetext{
${ }^{149}$ CJEU judgment of 16 July 2009, Commission versus Poland (GMOs), C-165/08, EU:C:2009:473, para 30.

${ }^{150}$ CJEU EC versus Poland (GMOs), C-165/08, para 31; emphases added.

${ }^{151}$ CJEU EC versus Poland (GMOs), C-165/08, para 52; emphases added.

${ }^{152}$ CJEU EC versus Poland (GMOs), C-165/08, para 51; emphases added.

${ }^{153} \mathrm{CJEU}$ EC versus Poland (GMOs), C-165/08, para 58.

${ }^{154}$ CJEU EC versus Poland (GMOs), C-165/08, para 56. In this case, the Court also did not refer to 'public morality' as a separate reason of justification, besides protection of human health and of the environment (para 55).
} 
to ethics and morality, thus in either case, the Court saw no necessity to determine the content of these concepts, as this decision was left to the MS, acting according to their values. This holds true for the above-mentioned sensitive fields, where the Court has observed "significant moral, religious and cultural differences". However, on a timeline, today, one would have to add the EU's common values. As stated in Omega, a consensus amongst the MS is no necessity and the Court accepts aspects that are specifically important for a country, such as human dignity for Germany, or for Italy, rejecting the mafia. In the latter situation, the General Court recently has accepted the non-registration of a figurative trademark "La Mafia" emphasizing "accepted principles of morality are not the same in all Member States, inter alia for linguistic, historic, social and cultural reasons". 155

The Court's technical legal approach can be welcomed as it leaves these decisions to the national level and to the citizens' representatives. However, one should not disregard the fact that in an indirect way also the legal approach will determine a medically or ethically sensitive topic. Due to this judicial self-restraint, the Court only provides sectoral solutions, thus no general statement with regard to the beginning of life. ${ }^{156}$

The limitations to this national discretion are the prohibition of double morality and the requirements of coherence and legislative transparency, or in other terms, a reduced (or 'procedural') proportionality review.

The relationship between law and ethics concerns similar issues, as the one of law and religion. In this context, there would have been very interesting topics in this GMO case, which in the end have not been answered, since Poland has not been able to prove its point of view.

After this qualitative analysis, let us have a brief look at some quantitative findings of analysing the terms of 'ethics' and 'morality' in CJEU case-law from 1961-2015. ${ }^{157}$ Focusing on those cases, where the Court itself has refereed to these terms (thus, excluding quotations of EU law or mere statements of parties, referring to these key terms), this research has revealed that more than $70 \%$ of cases have been decided since $1998,{ }^{158}$ with $29 \%$ references to ethics, $67 \%$ to morality, and $4 \%$ to both terms. ${ }^{159}$ This roughly corresponds with general 'ethicalization' since the 1990s.

\footnotetext{
${ }^{155}$ GC judgment of 15 March 2018, La Mafia Franchises, T-1/17, EU:T:2018:146, para 28. On the (new) regulation, see infra at note 369 .

${ }^{156}$ Mayr: transfer into uterus, Brüstle: fertilization, ISC: capacity to develop into a human being.

${ }^{157}$ The following empirical analysis is based on the research of Rudigier (2015).

158 1998-2003: 23\%; 2004-2009: 15\%; 2010-2015: 33\%.

${ }^{159}$ Rudigier (2015, p. 29).
} 


\subsubsection{Ethics in Law Making: Ethics Rules on Lobbying}

After EU primary law (the constitutional perspective) and international agreements (the external perspective), before turning to EU secondary (and tertiary) law (the internal legislative perspective, in terms of the output), we need to shed some light on the decision-making procedure itself. Lobbying is a much-contested topic, especially because of asymmetries regarding information, but also regarding resources in general. A lack of transparency often leads to mistrust, as we have seen in case of CETA. Similar to CETA and the fear of the possibility to 'buy justice' in the context of investment protection tribunals, lobbying is very much about the fear of citizens that large companies can simply 'buy legislation'.

None of the three decision-making powers of the EU, the EC, the EP nor the Council of the EU, mention either ethics or morality in their Rules of Procedure, ${ }^{160}$ and the same is true for the EU staff regulations. ${ }^{161}$ Thus, as mentioned above, ${ }^{162}$ for this chapter also implicit references will be taken into account, as there is no explicit mentioning of 'ethics' or 'morality'. Tracing these implicit references shall make it possible to answer the question, if the EU provides for 'ethical lobbying', and how the determination takes place. ${ }^{163}$

These implicit references occur in terms of principles such as integrity, diligence, honesty and accountability, which can refer either to the targets, or to the actors of lobbying. The majority of documents of this 'acquis légal \& éthique' concerns targets. ${ }^{164}$ Hence, we will start analysing the rules on these targets (comprising both political actors, as well as administrative staff), before moving to the actors, i.e. consultants and lobbyists, as well as experts.

\footnotetext{
${ }^{160}$ Frischhut (2015, pp. 539-541).

${ }^{161}$ Regulation No 31 (EEC), 11 (EAEC), laying down the Staff Regulations of Officials and the Conditions of Employment of Other Servants of the European Economic Community and the European Atomic Energy Community, OJ 1962 45/1385, as amended by OJ 2017 C 429/9 [Regulation staff].

${ }^{162}$ Note 54.

${ }^{163}$ The following chapter is based on Grad and Frischhut (2019), comprising further details on this topic.

${ }^{164}$ For an overview of the different documents see Grad and Frischhut (2019, pp. 309-310).
} 


\subsubsection{Rules on Targets}

Besides a general negative conception of lobbying ${ }^{165}$ and information asymmetries, ${ }^{166}$ the most common challenges with regard to targets of lobbying are conflicts of interest, acceptance of gifts and corruption, ${ }^{167}$ and finally the revolving doors phenomenon. They can be overcome by transparency, other general 'guiding principles' on 'ethical behaviour', rules on independence and accountability towards citizens and one's institution, and finally rules on post term-of-office.

Transparency plays a key role for lobbying and can contribute to more ethical lobbying in manifold ways. ${ }^{168}$ For instance, it can help to overcome information asymmetries, by enabling more equal access to information. At the same time, it can improve the quality of decisions taken, if these decisions (plus corresponding background information) can be known by others, and therefore be challenged. Transparency is an important principle of EU law, which is enshrined in Art 1 TEU and 10 TEU and in Art 15 TFEU. According to the CJEU, it "enables citizens to participate more closely in the decision-making process and guarantees that the administration enjoys greater legitimacy and is more effective and more accountable to the citizen in a democratic system". 169

In terms of 'guiding principles', the EP provides most principles in its Code of Conduct (EP CoC $)^{170}$; these are: "disinterest, integrity, openness, diligence, honesty, accountability and respect for Parliament's reputation". ${ }^{171}$ Integrity is also the principle that plays a key role for the independence of the Commission, whereas its members shall "behave with integrity and discretion"172 with regard to appointments or benefits, after they have ceased to hold office. In literature, integrity has been defined as "the quality of being honest and morally upright". ${ }^{173}$ In January 2018, the EC adopted a new Code of Conduct (EC CoC), which requires members to "behave

\footnotetext{
${ }^{165}$ This comprises activities "carried out with the objective of directly or indirectly influencing the formulation or implementation of policy and the decision-making processes of the EU institutions, irrespective of where they are undertaken and of the channel or medium of communication used"; Agreement between the EP and the EC on the transparency register for organisations and selfemployed individuals engaged in EU policy-making and policy implementation, OJ 2014 L 277/11 [Agreement transparency register], Art 7(1).

${ }^{166}$ James (2008).

${ }^{167}$ While lobbying can be seen to play a certain legitimate role in a democracy, corruption is part of the criminal sphere.

${ }^{168}$ Transparency has even been referred to as "a transversal value" and "might even become itself a virtue"; Hamm $(2018,119)$.

${ }^{169} \mathrm{CJEU}$ judgment of 9 November 2010, Schecke, C-92/09, EU:C:2010:662, para 68; emphases added.

${ }^{170} \mathrm{EP}$ Code of Conduct for Members of the European Parliament with respect to financial interests and conflicts of interest, http://www.europarl.europa.eu/sides/getDoc.do?pubRef=-//EP//TEXT+ RULES-EP+20180731+ANN-01+DOC+XML+V0//EN\&language=EN\&navigationBar=YES [EP CoC].

${ }^{171}$ Art 1(a) EP CoC.

172 Art 245(2) TFEU.

${ }^{173}$ Petrick (2008, p. 1141).
} 
and perform their duties with complete independence, integrity, dignity, with loyalty and discretion", as well as to "observe the highest standards of ethical conduct". ${ }^{174}$ The fact that these 'ethical standards' are not directly determined is less of a problem, as the principles mentioned before will very much contribute to the determination of these ethical standards. Integrity seems to be an important principle in this regard, as it is further determined in Art $6 \mathrm{CoC}$. This includes the requirement to manage the material resources of the EC in a "responsible manner", reluctance in the context of free travel offered by third parties and hospitality, not to accept gifts worth more than $€ 150,{ }^{175}$ as well as notification of any decoration, prize or honour awarded to them. For 'officials of the Union', i.e. the staff of EU institutions, several principles are addressed. These comprise objectivity, impartiality and loyalty to the EU, ${ }^{176}$ independence and avoidance of "actual or potential conflict of interest", ${ }^{177}$ "integrity and discretion" after leaving the service, ${ }^{178}$ as well as requirements for recruitment, "highest standard of ability, efficiency and integrity". ${ }^{179}$ In addition, for the Commission's staff the relevant document also mentions objectivity and impartiality as key principles, besides the 'general principles' of lawfulness, non-discrimination and equal treatment, proportionality and consistency. ${ }^{180}$ Although not a target of lobbying, also the CJEU in its recent code of conduct does not refer to ethics or morality as such, but operates based on principles, such as independence, integrity, dignity, impartiality, loyalty, discretion, and avoidance of a conflict of interest. ${ }^{181}$

Regarding its content, unethical behaviour very often can be explained in terms of a conflict of interest, which occurs in situations, where a person is faced with a clash of a personal interest and the public interest, this person has to represent. According to the EC Code of conduct, "[a] conflict of interest arises where a personal interest may influence the independent performance of their duties", or negatively defined, a conflict of interest does not exist if a member is only concerned as a member of the general public or of a broad class of persons. ${ }^{182}$ Transparency also plays a role here, in the avoidance of conflicts of interest, by means of disclosure obligations with regard to certain financial interests (occupation, board membership, company holdings, etc.). ${ }^{183}$

\footnotetext{
${ }^{174} \mathrm{EC}$ decision of 31 January 2018 on a Code of Conduct for the Members of the EC, OJ $2018 \mathrm{C}$ $65 / 7$ [EC CoC].

${ }^{175}$ Same threshold in Art 5(1) EP CoC.

${ }^{176}$ Art 11(1) Regulation staff.

${ }^{177}$ Art 11(3) Regulation staff.

${ }^{178}$ Art 16(1) Regulation staff.

${ }^{179}$ Art 12(1) and Art 27(1) Regulation staff.

${ }^{180}$ EC Rules of Procedure of the Commission (C(2000) 3614), OJ 2000 L 308/26, as amended by OJ 2011 L 296/58, Annex I, Code of good administrative behaviour for staff of the EC in their relations with the public.

${ }^{181}$ CJEU Code of Conduct for Members and former Members of the Court of Justice of the European Union, OJ 2016 C 483/1; according to Art 9, integrity, dignity, loyalty and discretion apply after their office as well.

${ }^{182}$ Art 2(6) EC CoC. In a very similar way: Art 3(1) EP CoC.

${ }^{183}$ Art 3 EC CoC; Art 4 EP CoC.
} 
The phenomenon of 'revolving doors' refers to situations, where former public officials start working in the private sector in jobs which target their former field of profession, or where individuals join an EU institution from the private sector. ${ }^{184}$ This can result in privileged access of certain interest groups to decision makers. According to the European Ombudsman, implementing rules on this phenomenon "is central to maintaining high ethical standards in public administrations". ${ }^{185}$ Based on recent scandals (e.g. 'Barrosogate' ${ }^{186}$ ), the EC CoC has strengthened the rules on 'post term of office activities', whereby the members continue to be bound by their duty of integrity and discretion ('cooling-off period'). ${ }^{187}$ This comprises, amongst others, the prohibition for former Commissioners to lobby members or their staff "on matters for which they were responsible within their portfolio for a period of two years after ceasing to hold office". ${ }^{188}$ In case of the president, this period is even three years. ${ }^{189}$ The EP has softer rules on lobbying, as former members of the EP (MEPs) just have to inform the EP and may not benefit from facilities granted to former MEPs, but lobbying as such is not prohibited. ${ }^{190}$ While the only possible argument could be seen in the bigger number of former MEPs, this topic is clearly a possibility for the EP to increase citizens' trust by strengthening these post-term rules. In terms of EU staff, "appointing authority shall, in principle, prohibit them, during the 12 months after leaving the service, from engaging in lobbying or advocacy vis-à-vis staff of their former institution". 191

All these substantive rules have to be accompanied by procedural safeguards. The EP has established an Advisory Committee on the Conduct of Members ('the Advisory Committee'), which shall make recommendations in the event of possible breaches of the EP's code of conduct. ${ }^{192}$ The requirements for qualification of its five members ${ }^{193}$ are not very ambitious, since it only requires "taking due account of the Members' experience and of political balance". ${ }^{194}$ Requested by the president of the $\mathrm{EP}$, the Advisory Committee shall examine the circumstances of the alleged breach, and may hear the MEP concerned. Based on its findings, the Advisory Committee makes a recommendation to the EP president concerning a possible decision. ${ }^{195}$ The Committee also has an important preventive function. If a possible conflict of

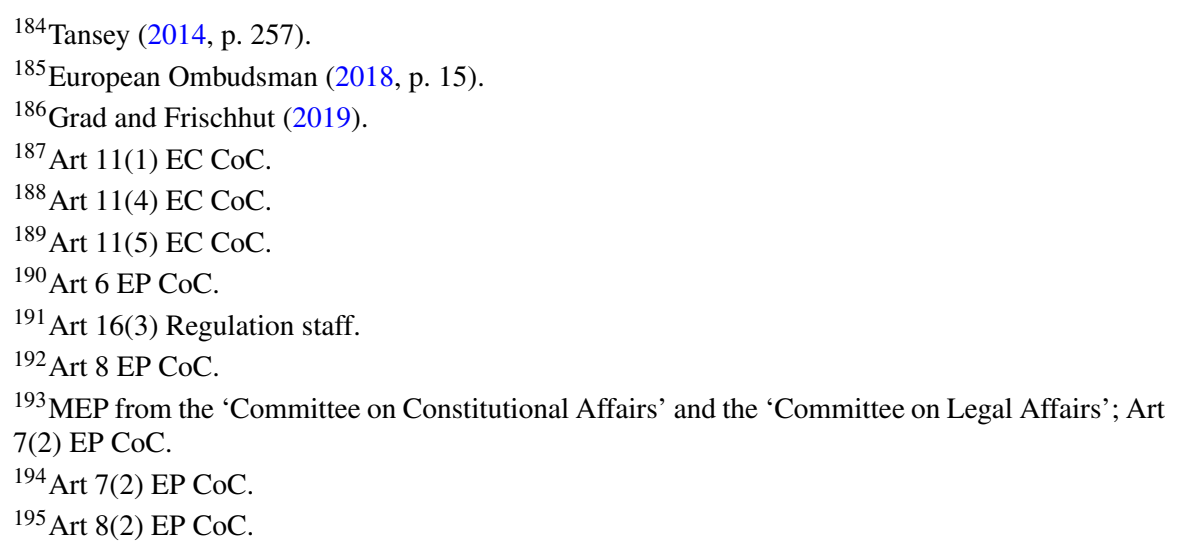


interest occurs, in case of ambiguity a MEP may seek advice in confidence from the Committee. ${ }^{196}$

The Commission clearly has set higher demands for the members of its ethics committee. The requirements for becoming a member of the 'Independent Ethical Committee' (IEC) are 'competence, experience, independence and professional qualities", in addition to "an impeccable record of professional behaviour as well as experience in high-level functions in European, national or international institutions"; moreover, they have to sign a declaration on the absence of conflicts of interest. ${ }^{197}$ The IEC shall advise the EC on "any ethical question" related to the EC $\mathrm{CoC}$ and provide general recommendations to the Commission on ethical issues in this regard. ${ }^{198}$ Unlike the EP's committee, the IEC can also include a "dissenting point of view" in its opinion. ${ }^{199}$ In case of the EC and a possible conflict of interest, it is not a member (as in case of the EP), but the EC president, who can consult the IEC, ${ }^{200}$ in a similar way as in cases of post term of office activities, ${ }^{201}$ with the possibility to make public the IEC opinion. ${ }^{202}$

\subsubsection{Rules on Actors}

As the EC nowadays often relies on outside expertise, rules on experts play an important role for ethical lobbying and can be positioned at the interface of targets and actors of lobbying. In fact, nowadays, it is a huge challenge to determine if in the context of decision-making, information is provided from a true expert, or from a 'disguised lobbyist'. That is why the EC has established horizontal rules on the creation and operation of EC expert groups, which strive for a balanced composition of expert groups and comprise rules on conflict of interest, in order to "ensure the highest level of integrity of experts". ${ }^{203}$

The EP and the EC have set up a transparency register and a code of conduct for lobbyists, which, unfortunately, is only voluntary. ${ }^{204,205}$ The European Council and the Council of the EU have been invited to join the register, but have not done so far. This code of conduct is more concrete and foresees 14 quite detailed obligations for lobbyists, addressing lobbyists' behaviour with regard to the EU institutions, their

\footnotetext{
${ }^{196}$ Art 3(2) EP CoC.

${ }^{197}$ Art 12(4) EC CoC.

${ }^{198}$ Art 12(1) EC CoC.

${ }^{199}$ Art 12(7) EC CoC.

${ }^{200}$ Art 4(4) EC CoC.

${ }^{201} \operatorname{Art} 11(3)$ EC CoC.

${ }^{202}$ Art 11(7) EC CoC.

${ }^{203} \mathrm{EC}$ decision establishing horizontal rules on the creation and operation of Commission expert groups, C(2016) 3301 final 30.5.2016 [EC decision experts], recital 3, Art 2(4), Art 11.

${ }^{204}$ The worst that can happen to a lobbyist who is in the register and does not comply, is a removal from the register and a loss of incentives provided by the register, like an access badge to the EP.

${ }^{205}$ Annex III of Agreement transparency register (OJ 2014 L 277/21).
} 
members, officials and other staff. It also entails transparency, operates less based on principles for ethical behaviour, and just mentions 'honesty' in the context of how information or decisions are obtained.

\subsubsection{Conclusion}

The overall approach in the context of decision-making is not one as we have seen it so far, i.e. referring to terms of ethics and morality. Rather, the relevant documents refer to certain principles, which are important to attain the same objective, that is to say ethical behaviour of either side, of both actors and targets of lobbying, as well as of 'true' experts. One key principle is also to avoid a situation of an actual or potential conflict of interest. Other principles comprise accountability, dignity, diligence, discretion, disinterest, honesty, impartiality, independence, integrity, loyalty, objectivity, openness, responsibility, and transparency. These principles (among which especially transparency) are of utmost importance to (re-)gain citizens' trust. Intransparent decision-making as well as unethical behaviour will further widen the gap between the EU and its citizens. The already mentioned CETA agreement was a clear example of decreasing trust by not providing sufficient transparency. The Commission seemed to have learned from this example, as the Brexit negotiations are more open and documents more easily accessible.

These principles have to apply both during, and partially also after holding a certain office. Moreover, these substantive rules have to be accompanied by procedural rules, as is the case for the two committees of the EP and the EC. These committees not only play an important role in a concrete situation, but also have an important preventive function. Comparing these two committees, the EC's IEC is clearly more ambitious with regard to the requirements of becoming a member, and allows for dissenting opinions, where an opinion is not adopted unanimously. Beside this, every ethics or expert committee ideally should strive for a balanced composition of its qualified members. With regard to the legal quality of these documents, we have seen both examples of hard law (e.g. the regulation on EU staff), as well as soft-law documents.

\subsubsection{Ethics and Morality in EU Secondary (and Tertiary) Law}

Following the vertical hierarchy of EU law, we now turn to EU secondary law, mainly enacted by the EP and the Council, as well as some examples of tertiary EU law, enacted based on the former. Not surprisingly due to the number of EU legal documents in this field, also the largest number of documents referring to ethics and/or morality can be found here. As it has been mentioned in the introduction, the objective of this book is not to create an inventory of all the examples of EU law, which refer to ethics and/or morality. Hence, in the following, the essence of this 
research conducted in two waves will be presented by means of some noteworthy examples. $^{206}$

This chapter starts with some examples of consequences of unethical behaviour, remarks concerning the requirement of legal certainty (Sect. 3.3.3.1). This research was mainly conducted in English, also taking into account other languages. That is why in a next step, some language inconsistencies will be highlighted (Sect. 3.3.3.2), before turning to the main part of categorizing the way how ethics and morality are determined regarding their content in EU secondary (and tertiary) law (Sect. 3.3.3.3).

\subsubsection{Consequences of Unethical Behaviour, as Well as Legal Certainty (Continued)}

The consequences of (non-)compliance with ethics, if mentioned in an EU legal document, can be seen from various examples. EU rules on authorisation and supervision of genetically modified food and feed require, amongst others "a reasoned statement that the food does not give rise to ethical or religious concerns". ${ }^{207}$ In addition, the EU regulation on clinical trials requires prior authorisation, whereby a "clinical trial shall be subject to scientific and ethical review". ${ }^{208}$

Moreover, we can see the consequences of unethical behaviour in the context of Horizon 2020, where "[r] esearch and innovation activities supported by Horizon 2020 should respect fundamental ethical principles". 209 A "proposal which contravenes ethical principles [...] may be excluded from the evaluation, selection and award procedures at any time" 210 ; in addition the Commission "shall systematically carry out ethics reviews for proposals raising ethical issues", ${ }^{211}$ and the grant agreement has to acknowledge "the right of the Commission to carry out an ethics audit by independent experts". ${ }^{212}$ Based on what we have seen in the chapter on the CJEU's case-law on stem cell patentability, ${ }^{213}$ it is no surprise that " $[\mathrm{t}]$ he use, if any, of human stem cells, be they adult or embryonic, [...] is subject to stringent ethics review". 214

\footnotetext{
${ }^{206}$ The following chapter is based on the research by Frischhut (2015) (also entailing further examples); this research has been updated by the author.

${ }^{207}$ Regulation (EC) No 1829/2003 of 22 September 2003 on genetically modified food and feed, OJ 2003 L 268/1, as amended by OJ 2015 L 327/1 [Regulation GM food], Art 5(3)(g).

${ }^{208}$ Regulation clinical trials, Art 5.

${ }^{209}$ Regulation (EU) No 1291/2013 of 11 December 2013 establishing Horizon 2020-the Framework Programme for Research and Innovation (2014-2020) [...], OJ 2013 L 347/104, as amended by OJ 2015 L 169/1 [Regulation establishing Horizon 2020], recital 29.

${ }^{210}$ Regulation (EU) No 1290/2013 of 11 December 2013 laying down the rules for participation and dissemination in "Horizon 2020 - the Framework Programme for Research and Innovation (2014-2020)" [...], OJ 2013 L 347/81, as amended by OJ 2014 L 174/14 [Regulation participation Horizon 2020], Art 13(3).

${ }^{211}$ Regulation participation Horizon 2020, Art 14(1).

${ }^{212}$ Regulation participation Horizon 2020, Art 18(6).

${ }^{213}$ Supra Sect. 3.3.1.1.

${ }^{214}$ Regulation establishing Horizon (2020), recital 31; emphasis added.
} 
Although only soft-law, the 'European Charter for Researchers' states that "[r]esearchers need to be aware that they are accountable towards their employers, funders or other related public or private bodies as well as, on more ethical grounds, towards society as a whole." 215 In the context of fishery, we find a responsibility for the "correct and appropriate use of the data with regard to scientific ethics". ${ }^{216}$

In cross-border healthcare, EU patient mobility rights are limited according to the corresponding directive insofar as these rights may not be used in a way which "undermin[es] the fundamental ethical choices of Member States". ${ }^{217}$ Nevertheless, which kind of medical, health, or related treatment ${ }^{218}$ should be qualified as unethical $?^{219}$ These are only some examples that raise a number of important questions: Is there a definition or at least a certain form of understanding as to what has to be understood by 'ethical'?

As mentioned above, as part of EU's common values, ${ }^{220}$ the 'the rule of law',21 according to the EC's recent communication, ${ }^{222}$ also entails legal certainty. According to the CJEU, this requires that "legislation must be clear and predictable for those who are subject to it". 223 Thus, one might wonder, if EU legislation referring to ethics and morality is clear and predictable and "formulated with sufficient precision to enable the individual to regulate his or her conduct", ${ }^{224}$ or whether it remains undetermined in the end?

This might be less of a problem, if legal documents refer to "minor's physical, mental, spiritual, moral and social development", ${ }^{225}$ the "physical, mental and moral

\footnotetext{
${ }^{215}$ EC recommendation 2005/251/EC of 11 March 2005 on the European Charter for Researchers and on a Code of Conduct for the Recruitment of Researchers, OJ 2005 L 75/67 [EC Charter researchers], Annex, Section 1.

${ }^{216}$ Regulation (EU) 2017/1004 of 17 May 2017 on the establishment of a Union framework for the collection, management and use of data in the fisheries sector and support for scientific advice regarding the common fisheries policy [...], OJ 2017 L 157/1 [Regulation data fisheries], Art 20(1)(c).

${ }^{217}$ Directive 2011/24/EU of 9 March 2011 on the application of patients' rights in cross-border healthcare, OJ 2011 L 88/45, as amended by OJ 2013 L 353/8 [Directive patient mobility], recital 7.

${ }^{218}$ For a visualized overview see Hall (2013, p. 12).

${ }^{219}$ See infra at note 351 .

${ }^{220}$ Supra Sect. 3.1.3.

${ }^{221}$ Cf. Bogdandy and Ioannidis (2014, 62-63), Bogdandy, Bogdanowicz, Canor, Taborowski, and Schmidt (2018).

${ }^{222} \mathrm{COM}$ (2014) 158 final 11.3.2014, p. 4 and Annex 1.

${ }^{223} \mathrm{CJEU}$ Meridionale Industria Salumi, 212 to 217/80, para 10.

${ }^{224}$ Venice Commission, Report on the Rule of Law, CDLAD(2011)003rev, 10.

${ }^{225}$ Directive 2013/33/EU of 26 June 2013 laying down standards for the reception of applicants for international protection, OJ 2013 L 180/96, Art 23(1).
} 
integrity" 226 of victims of crime, or the "morals of young persons". ${ }^{227}$ In the other cases mentioned above, the missing determination of unethical behaviour can have important consequences.

However, before we turn to the determination of content, let us take a closer look at the different language versions of EU documents referring to ethics and morality.

\subsubsection{Language Inconsistencies}

In the context of a Union with 24 different languages, ${ }^{228}$ it is important to follow a linguistically holistic ${ }^{229}$ approach. As we have just seen, ethics and morality, in theory, have a different meaning and therefore it is astonishing that they are used differently in different language versions. What reads "[c]onsumers in the [EU] would [...] find it morally unacceptable that their increased use of biofuels could have the effect of destroying biodiverse lands" ${ }^{230}$ in the English version, ${ }^{231}$ refers to ethics ("ethisch inakzeptabel") in the German version. ${ }^{232}$ However, as those terms are generally distinguished, we can assume that this wording is based on imprecise translation and without further significance.

The same might hold true for the case of the already mentioned Directive Biotech, ${ }^{233}$ which refers to the "ethical or moral principles recognised in a [sic!] Member State", ${ }^{234}$ whereas the German version uses the plural ("in den Mitgliedstaaten"). ${ }^{235}$ As mentioned above in the context of human dignity, the number of

\footnotetext{
${ }^{226}$ Directive 2012/29/EU of 25 October 2012 establishing minimum standards on the rights, support and protection of victims of crime, and replacing Council Framework Decision 2001/220/JHA, OJ 2012 L 315/57, recital 9.

${ }^{227}$ Council Directive (EU) 2017/159 of 19 December 2016 implementing the Agreement concerning the implementation of the Work in Fishing Convention, 2007 of the International Labour Organisation [...], OJ 2017 L 25/12, Art 6.

${ }^{228}$ According to Art 55(1) TEU and Art 358 TFEU, the Treaties (Primary law) are "equally authentic" in each of these 24 languages. The same is true for Secondary law, comprising 24 "official languages and the working languages of the institutions of the Union"; Council Regulation No 1 Determining the Languages to be Used by the European Economic Community, OJ 1958 P 17/385,

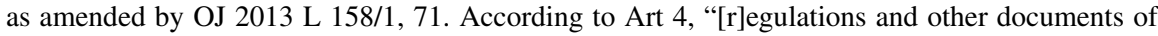
general application shall be drafted in the official languages".

${ }^{229} \mathrm{As}$ a limitation it has to be stated, that beside English (EN), these will be the languages spoken (German, DE; French, FR; Spanish, ES) or at least passively understood (Italian, IT) by the author.

${ }^{230}$ Directive 2009/30/EC of 23 April 2009 [amending certain other directives], OJ 2009 L 140/88 [Directive greenhouse gas emissions], recital 11; emphasis added.

${ }^{231}$ Similar in FR, ES, IT.

${ }^{232}$ For a similar example see also CJEU judgment of 5 December 1996, Merck, C-267/95, EU:C:1996:468, para 53 ("ethical obligations" versus "moralische Verpflichtungen").

${ }^{233}$ Recital 39.

${ }^{234}$ Similar in FR, ES, IT.

${ }^{235}$ According to de Witte (2013, p. 1558), "the preamble to Directive 98/44 speaks of the respect for the ethical or moral principles recognized in $a$ Member State, $[\ldots]$ and the European Parliament long halted the decision-making process by referring to the irreconcilable differences of opinion
} 
MS sharing a certain conception can play an important role in case of authorities of a MS issuing a restrictive measure. ${ }^{236}$

Although this will be the compelling solution, it might sound funny if only the English version of a code of conduct (relating to transactions in transferable securities) declares the code's objective as "to establish standards of ethical behaviour on a Community-wide basis", whereas the other language version examined only refer to loyal behaviour (for example, FR: “comportement loyal"237). ${ }^{238}$

There are other examples of differences in translation which can be clustered into a less problematic category, where the term 'ethical' is just explicitly missing - but to some degree implicitly included-in another language version.

A first example refers to the degree to which substances can be tested on animals. ${ }^{239}$ Here, only the German version refers to ethics, ${ }^{240}$ whereas a similar idea is worded in different ways in English ("can humanely be allowed" similarly in ES), and the French (and IT) version referring to the degree of pain suffered by the animal (FR: "sans que cela fasse trop souffrir l'animal").

A second example refers to doping, where the use of drugs in sport is denounced as "unsporting behaviour" in the English version, whereas all the other examined versions refer to the ethics of the sport (for example, ES: "contrario a la ética deportiva"). ${ }^{241}$ Therefore, in both cases, the result might be the same, but the wording is different.

The same is true, if the term code of conduct ("Verhaltenskodex") is used in one version (DE), whereas the other languages examined use the term code of ethics, and so on. ${ }^{242}$ In a similar way, concerning ethical rules of a professional nature, one has to be aware of the fact that often professional rules ${ }^{243}$ in one language version (DE:

\footnotetext{
between the Member States, highlighting that it should be for States and their citizens to make their own assessments of these divisive moral questions"; no emphasis added.

${ }^{236}$ See supra at note 142.

${ }^{237} \mathrm{EC}$ recommendation 77/534/EEC of 25 July 1977 concerning a European code of conduct relating to transactions in transferable securities, OJ 1977 L 212/37 [EC recommendation securities], Annex.

${ }^{238}$ For further examples, see Frischhut (2015, p. 538).

${ }^{239}$ Council Regulation (EC) No 440/2008 of 30 May 2008 laying down test methods pursuant to Regulation (EC) No 1907/2006 on the Registration, Evaluation, Authorisation and Restriction of Chemicals (REACH), OJ 2008 L 142/1, as amended by OJ 2017 L 112/1, Annex, Part B.4, 1.4.2.3. ${ }^{240} \mathrm{DE}$ : "ethisch verantwortbar".

${ }^{241}$ Resolution of the Council [etc.] of 3 December 1990 on Community action to combat the use of drugs, including the abuse of medicinal products, particularly in sport, OJ 1990 C 329/4, Annex I.

${ }^{242}$ Council Decision 2008/210/EC of 18 February 2008 on the principles, priorities and conditions contained in the European Partnership with Albania [etc.], OJ 2008 L 80/1 [Council decision Albania], Annex, pt. 3.1; FR: "code de déontologie", ES: "el código deontológico", IT: "codice ético".

${ }^{243}$ Directive 2005/36/EC of 7 September 2005 on the recognition of professional qualifications, OJ 2005 L 255/22, as amended by OJ 2017 L 317/119 [Directive recognition qualifications].
} 
"standesrechtlichen Regeln") correspond to "rules of professional ethics" in other versions. $^{244}$

To sum it up, we can say that the general EU rule to take into account not only one language version of course also helps in case of the language inconsistencies in our context. However, in case of fundamental concepts like 'ethics' or 'morality', more "clarity and consistency" 245 would be desirable. Still, it can also rest unclear if the language versions that are 'united in diversity' are due to imprecise translations (for example, somewhere in a very comprehensive annex), or are the result of debates on principles.

\subsubsection{Status Quo of Ethics and Morality}

In EU primary law, we have seen 'morality' used as an umbrella to protect MS from EU interference in sensitive fields. ${ }^{246}$ We can find a similar [1.] 'protection shield'-approach in EU secondary law. As we have already seen in the context of Horizon 2020, the use of human stem cells is "subject to stringent ethics review"; this provision continues by stating that "[n]o project involving the use of human embryonic stem cells should be funded that does not obtain the necessary approvals from the Member States". 247

The wording is even stronger in case of genetically modified food and organisms, where reference is made to "competence [sic] of Member States as regards ethical issues." 248

The example of EU patient mobility has already been mentioned in terms of consequences of unethical behaviour. According to this directive, patients' rights are limited insofar as these rights may not be used in a way which "undermin[es] the fundamental ethical choices of Member States". ${ }^{249}$ This reference to the term 'ethics' in this EU legal document is clearly motivated by the fear that a broad interpretation of the term "health services" could entitle EU citizens to use certain

\footnotetext{
${ }^{244}$ Directive 2006/123/EC of 12 December 2006 on services in the internal market, OJ 2006 L 376/36 [Directive services], recital 99 (et passim); EN: "ethical rules laid down by professional bodies"; DE: "von den Berufsverbänden festgelegten Standesregeln".

${ }^{245}$ In that context, according to the Interinstitutional Agreement [EP, Council, EC] on Better LawMaking, OJ 2016 L 123/1 [IIA Better Law-Making], pt. 2, these institutions "agree to promote simplicity, clarity and consistency in the drafting of Union legislation"; emphasis added. According to the Joint Declaration [of the same three institutions] on practical arrangements for the co-decision procedure [...], OJ $2007 \mathrm{C} 145 / 5$, "[n] o changes shall be made to any agreed texts without the explicit agreement, at the appropriate level, of both the [EP] and the Council" (pt. 41), after "the agreed text [has been] finalised by the legal-linguistic services of the [EP] and of the Council acting in close cooperation and by mutual agreement" (pt. 40).

${ }^{246}$ Supra Sect. 3.1.2.

${ }^{247}$ Regulation establishing Horizon 2020, recital 31; emphasis added.

${ }^{248}$ Regulation GM food, recital 42.

${ }^{249}$ Directive patient mobility, recital 7.
} 
sensitive health services abroad. ${ }^{250}$ Thus, ethics, again, serves as a protection shield against EU interference.

Moreover, we have also already seen the example of Directive Biotech, which, amongst others, excludes the patentability of "uses of human embryos for industrial or commercial purposes". ${ }^{251}$ The TRIPs Agreement foresees the possibility to exclude inventions from patentability, if they are against ordre public or morality. ${ }^{252}$ When making use of this possibility, the directive makes clear that "ordre public and morality correspond in particular to ethical or moral principles recognised in a Member State" 253 ; hence, not at EU level. Further examples of referring to the national level for the determination of ethics can be found in the field of research. ${ }^{254}$

After this category of ethics being used as a 'protection shield', we find another category, where ethics (or morality ${ }^{255}$ ) is used as [2.] a supportive argument for a certain legal solution. Here, it is less of a problem, if the content of ethics is not determined, as the legal solution itself might fulfil the requirements of legal certainty. This is the case for the statement that consumers in the EU would "find it morally unacceptable that their increased use of biofuels could have the effect of destroying biodiverse lands", ${ }^{256}$ or that "[c]onsumers' choices can be influenced by, inter alia, health, economic, environmental, social and ethical considerations". ${ }^{257}$ In another example, the killing of seals is qualified as morally problematic as such, beside commercial killing being qualified as more problematic than traditional hunting by Inuit. $^{258}$

\footnotetext{
${ }^{250}$ See infra at note 351 .

${ }^{251}$ Art 6(2)(c).

${ }^{252}$ Recital 36.

${ }^{253}$ Recital 39.
}

${ }^{254}$ Council Decision (EU) 2017/955 of 29 May 2017 amending Decision 2008/376/EC on the adoption of the Research Programme of the Research Fund for Coal and Steel and on the multiannual technical guidelines for this programme, OJ 2017 L 144/17 [Council Decision Research Coal and Steel], Art 29a(6): "Participants shall comply with national legislation, regulations and ethical rules in the countries where the action is carried out"; EC Charter researchers, Annex, Section 1: "Researchers should adhere to the recognised ethical practices and fundamental ethical principles appropriate to their discipline(s) as well as to ethical standards as documented in the different national, sectoral or institutional codes of ethics."

${ }^{255}$ Council Regulation (EU) 2016/369 of 15 March 2016 on the provision of emergency support within the Union, OJ 2016 L 70/1, recital 1: "Mutual assistance and support in the face of disasters is both a fundamental expression of the universal value of solidarity between people and a moral imperative, as such disasters may lead to a significant number of people being unable to meet their basic needs, with potential severe adverse effects on their health and lives".

${ }^{256}$ Directive greenhouse gas emissions, recital 11.

${ }^{257}$ Regulation (EU) No 1169/2011 of 25 October 2011 on the provision of food information to consumers, OJ 2011 L 304/18, as amended by OJ 2015 L 327/1, recital 3, see also Art 3(1).

${ }^{258}$ Regulation (EU) 2015/1775 of 6 October 2015 amending Regulation (EC) No 1007/2009 on trade in seal products [...], OJ 2015 L 262/1 [Regulation seal products]: “[...] public moral concerns about the animal welfare aspects of the killing of seals and the possible presence on the Union market of products obtained from seals killed in a way that causes excessive pain, distress, fear and other forms of suffering" (recital 1); "For those reasons, seal hunts traditionally conducted by Inuit and 
In context of 'novel food', we find a supportive argument to contribute to animal welfare and ethics: "[...] tests on animals should be replaced, reduced or refined. Therefore, [...] duplication of animal testing should be avoided, where possible. Pursuing this goal could reduce possible animal welfare and ethical concerns with regard to novel food applications". 259

Apart from ethics used as a supportive argument, we can further identify references in order to create [3.] a parallel ethical assessment beside the legal one. In this category, we can identify coexistence of law and ethics (that is to say, a parallel system), with Directive Biotech stating that "substantive patent law cannot serve to replace or render superfluous [...] compliance with certain ethical standards" 260 and that "ethical or moral principles supplement the standard legal examinations under patent law". ${ }^{261}$ The same holds true in the field of protection of the EUs financial interests, where the definition of 'professional misconduct' "means violation of laws or regulations or of ethical standards of the profession to which the person belongs" ${ }^{262}$

In the field of transferable securities, we find a noteworthy statement of the European Commission concerning the relationship of EU harmonization and ethics. "This code of conduct, to be issued in the form of a Commission recommendation, must be seen separately from the Commission's other harmonization work in this sector [...] because the ethical approach has been given priority over the legislative approach". 263

A similar parallelism can be found in case of staff responsibility (of the EU Institute for Security Studies): "Employees shall abstain from any public action or statement or publication if such action, statement or publication is incompatible with the duties or obligations of an international civil servant or liable to involve the moral or material responsibility of the Institute."264

In addition to the parallelism of law and ethics, a similar relation can be addressed between science and ethics. In the context of Registration, Evaluation, Authorisation

other indigenous communities do not raise the same public moral concerns as seal hunts conducted primarily for commercial reasons" (recital 2).

${ }^{259}$ Regulation (EU) 2015/2283 of 25 November 2015 on novel foods [...], OJ 2015 L 327/1 [Regulation novel foods], recital 32; emphases added.

${ }^{260}$ Recital 14, emphases added. See also CJEU judgment of 9 October 2001, Netherlands versus EP and Council, C-377/98, EU:C:2001:523, para 80.

${ }^{261}$ Recital 39, emphases added. See also Presidency Conclusions, Stockholm European Council (23./24.3.2001), part I, VI. 44.

${ }^{262}$ EC decision 2014/792/EU of 13 November 2014 on the Early Warning System to be used by authorising officers of the EC and by the executive agencies, OJ 2014 L 329/68, Art 2(g); emphases added. See also Regulation (EU, Euratom) 2018/1046 of 18 July 2018 on the financial rules applicable to the general budget of the Union, OJ 2018 L 193/1 [Regulation financial rules], Art 136(1)(c).

${ }^{263} \mathrm{EC}$ recommendation securities, pt. 5 .

${ }^{264}$ Council Decision (CFSP) 2016/1182 of 18 July 2016 concerning the Staff Regulations of the European Union Institute for Security Studies, OJ 2016 L 195/31, Annex, Art 2(7)(c). 
and Restriction of Chemicals (REACH), we find several references to the requirement of being both "scientifically and ethically justified". ${ }^{265,266}$

These parallel situations are extended to a more holistic view in case of the EC proposal on health technology assessment (HTA), which refers to economic, medical, organisational, social, legal and ethical issues. ${ }^{267}$

After ethics only serving as a 'protection shield', or being used as a 'supportive argument', we have now seen ethics in terms of a parallel assessment of legal as well as ethical requirements. Already the last category requires a substantive determination, of what is meant by (un-)ethical behaviour. This leads us to our next (and very important) category, of [4.] ethics being determined by 'ethics committees'. There are committees, which focus exclusively on ethics, or others, where ethics is one of the aspects to be covered. ${ }^{268}$ These committees can be installed either at [a.] EU or at [b.] national level and can take various forms. The underlying idea of all these committees is to outsource this ethical assessment, in order to achieve independent, objective and good quality opinions.

However, there are also examples where the $\mathrm{EC}^{269}$ itself is tasked with the assessment at [4.a.] EU level. In Horizon 2020 the EC "shall systematically carry out ethics reviews for proposals raising ethical issues" by verifying "the respect of ethical principles and legislation". ${ }^{270}$ From a procedural perspective, this "process of the ethics review [has to be] as transparent as possible and [...] carried out in a timely manner". ${ }^{271}$ The "grant agreement shall, where appropriate, contain provisions ensuring the respect of ethical principles, including the establishment of an independent ethics

\footnotetext{
${ }^{265}$ EC Regulation (EU) $2017 / 735$ of 14 February 2017 amending, for the purpose of its adaptation to technical progress, the Annex to Regulation (EC) No 440/2008 laying down test methods pursuant to Regulation (EC) No 1907/2006 on the Registration, Evaluation, Authorisation and Restriction of Chemicals (REACH), OJ 2017 L 112/1, Annex, passim.

${ }^{266}$ See also Regulation clinical trials, Art 2(2)(30): “'Good clinical practice' means a set of detailed ethical and scientific quality requirements [...]"; emphasis added; and Regulation medical devices, recital 71.

${ }^{267} \mathrm{EC}$ proposal for a regulation on HTA and amending [Directive patient mobility], $\operatorname{COM}(2018)$ 51 final 31.1.2018, recital 3 (et passim).

${ }^{268}$ Regulation (EC) No 1394/2007 of 13 November 2007 on advanced therapy medicinal products [...], OJ 2007 L 324/121, as amended by OJ 2010 L 348/1 [Regulation advanced therapy], Art 21(2) provides for a 'Committee for Advanced Therapies' and requires a "balanced coverage of the scientific areas relevant to advanced therapies, including medical devices, tissue engineering, gene therapy, cell therapy, biotechnology, surgery, pharmacovigilance, risk management and ethics".

${ }^{269}$ I will not further elaborate on examples of 'comitology', where the EC takes implementing measures on professional ethics, as for example, in Directive 2006/43/EC of 17 May 2006 on statutory audits of annual accounts and consolidated accounts [...], OJ $2006 \mathrm{~L} 157 / 87$, as amended by OJ 2014 L 158/196 [Directive statutory audits], recital 9.

${ }^{270}$ Regulation participation Horizon 2020, Art 14(1).

${ }^{271}$ Regulation participation Horizon 2020, Art 14(2).
} 
board and the right of the Commission to carry out an ethics audit by independent experts". 272,273

Due to its importance for our topic, the already mentioned EGE will be covered in a distinct chapter. ${ }^{274}$ However, it has also been tasked by different legal documents with ethical assessments. One year after the EGE's establishment in 1997, Directive Biotech provided that the EGE "evaluates all [sic!] ethical aspects of biotechnology". ${ }^{275}$ In the field of GMOs, the already mentioned Directive on the deliberate release into the environment, ${ }^{276}$ provides that "the Commission shall, on its own initiative or at the request of the [EP] or the Council, consult any committee it has created with a view to obtaining its advice on the ethical implications of biotechnology, such as [EGE], on ethical issues of a general nature". ${ }^{277}$ Such consultation has to be "conducted under clear rules of openness, transparency and public accessibility". ${ }^{278}$ Always keeping in mind the fact that EGEs opinions are not legally binding, the wording in 'Regulation GM food' is alleviated, as the "Commission, on its own initiative or at the request of a Member State, may consult [EGE] or any other appropriate body". ${ }^{279}$ Not as regards the procedure (consultation), but to the output, it is stated that the opinions have to be made "available to the public". 280

Apart from the EGE, there are several other institutional ethics committees, notably in the financial field. The European Investment Bank (EIB) follows a combined institutional and substantive approach, by having established an 'Ethics and Compliance Committee', which "shall rule on any potential conflict of interest" based on legal—not ethical—provisions. ${ }^{281}$ Recently, the EIB has strengthened the role of this Committee "by introducing the possibility for this Committee to provide opinions on any ethical matter concerning a member of the Management Committee or of the Board of Directors". ${ }^{282}$ In addition, the European Central Bank (ECB) follows a combined approach for the TARGET2-Securities Board, consisting of a code

\footnotetext{
${ }^{272}$ Regulation participation Horizon 2020, Art 18(6); emphases added.

${ }^{273}$ Further details implementing this legal requirement can be found on the EC's website: http://ec. europa.eu/research/participants/docs/h2020-funding-guide/cross-cutting-issues/ethics_en.htm.

${ }^{274}$ See infra Sect. 4.2 .

${ }^{275}$ Recital 44 and Art 7.

${ }^{276}$ At notes 75 and 148 .

${ }^{277}$ Art 29(1) Directive GMOs; emphases added.

${ }^{278}$ Art 29(2) Directive GMOs.

${ }^{279}$ Art 33(1) Regulation GM food.

${ }^{280}$ Art 33(2) Regulation GM food.

${ }^{281}$ Decision of the Board of Governors of 12 May 2010 on the amendment of the Rules of Procedure of the European Investment Bank to reflect the entry into force of the Treaty of Lisbon and of the new Statute of the Bank, OJ 2011 L 266/1, Art 11(4).

${ }^{282}$ Decision of the Board of Governors of 20 January 2016 on the Amendments to the Rules of Procedure of the EIB to reflect the Strengthening of the EIB Governance [2016/772], OJ 2016 L $127 / 55$, recital 2; emphasis added.
} 
of conduct ${ }^{283}$ and an 'Ethics Officer'. ${ }^{284}$ Members can contact the Ethics Officer in order to seek advice on an ad hoc basis. ${ }^{285}$ The $^{2} \mathrm{ECB}^{286}$ itself has established an 'Ethics Committee', due to the "increased level of public awareness and scrutiny [which] requires the ECB to have in place, and strictly adhere to, state-of-the-art ethics rules in order to safeguard the ECB's integrity and avoid reputational risks" ${ }^{287}$; it shall provide advice on questions of ethics based on individual requests. ${ }^{288}$

Finally, in a similar way as the EGE advises the EC, the 'European Data Protection Supervisor' has appointed an 'Ethics Advisory Group' as an "external advisory group on the ethical dimensions of data protection". ${ }^{289}$ One reason for the establishment of this Body is technological advancement (big data computing and machine learning), which allows for the collection and usage of personal data "in increasingly opaque and complex ways, thus posing significant threats to privacy and human dignity". ${ }^{290}$

Apart from ethics committees at EU level, there are also examples of ethics committees at [4.b.] national level.

A combined approach of both EU (the role of the EC has already been described) and national ethical scrutiny can be found in Horizon 2020. There participants are not only obliged to "comply with national legislation, regulations and ethical rules in the countries where the action will be carried out", but also "[w]here appropriate, [to] seek the approval of the relevant national or local ethics committees prior to the start of the action". 291

Also in the field of the research fund for coal and steel, participants shall, where appropriate, "seek the approval of the relevant national or local ethics committees prior to the start of the action". 292

\footnotetext{
${ }^{283}$ The code of conduct contains well-known principles such as avoidance of conflicts of interest (plus an obligation of notification in such situations), confidentiality, transparency and openness, an obligation of information and sanctions in the case of non-compliance (Annex III).

${ }^{284}$ Decision 2012/235/EU (ECB/2012/6) of the European Central Bank of 29 March 2012 on the establishment of the TARGET2-Securities Board [...], OJ 2012 L 117/13, as amended by OJ 2017 L 199/24, Annex III.

${ }^{285}$ Ibid. pt. 5.

${ }^{286}$ See also: Supplementary Code of Ethics Criteria for the members of the Executive Board of the European Central Bank, OJ 2010 C 104/8; Decision (EU) 2016/456 (ECB/2016/3) of the European Central Bank of 4 March 2016 concerning the terms and conditions for European Anti-Fraud Office investigations of the European Central Bank, in relation to the prevention of fraud, corruption and any other illegal activities affecting the financial interests of the Union, OJ 2016 L 79/34, with further information in recital 2.

${ }^{287}$ Decision (EU) 2015/433 (ECB/2014/59) of the European Central Bank of 17 December 2014 concerning the establishment of an Ethics Committee and its Rules of Procedure, OJ 2015 L 70/58, recital 2; emphases added.

${ }^{288}$ Ibid. Art 4(1).

${ }^{289}$ European Data Protection Supervisor Decision of 3 December 2015 establishing an external advisory group on the ethical dimensions of data protection ('the Ethics Advisory Group'), OJ 2016 C 33/1, Art 1(1).

${ }^{290}$ Ibid. recital 5; emphases added.

${ }^{291}$ Regulation participation Horizon 2020, Art 23(9).

${ }^{292}$ Council Decision Research Coal and Steel, Art 29a(6).
} 
It is again Directive GMOs, which states "Member States should be able to consult any committee they have established with a view to obtaining advice on the ethical implications of biotechnology". ${ }^{293}$ This statement stands beside the abovementioned possibility of the EC, to consult the EGE "on ethical issues of a general nature". ${ }^{294}$ Evaluation by and consultation with national or local ethics committees is also foreseen for nanosciences and nanotechnologies research, ${ }^{295}$ or in the case of ionizing radiation. ${ }^{296}$

In the field of 'clinical trials', 297 'medical devices' 298 and 'in vitro diagnostic medical devices' ${ }^{299}$ the three corresponding regulations all operate based on the same following definition of an ethics committee. "'Ethics committee' means an independent body established in a Member State in accordance with the law of that Member State and empowered to give opinions for the purposes of this Regulation, taking into account the views of laypersons, in particular patients or patients' organisations". 300 The ethical review performed by this national ethics committee is a requirement for prior authorisation, where a "clinical trial shall be subject to scientific and ethical review" ${ }^{301}$; similar rules apply for the two other examples mentioned above. ${ }^{302}$

Hence, as we have seen, ethics committees cannot only issue opinions on request or on their own initiative (for example, EGE), but can also play a decisive role in authorization procedures, not only for research grants, but also for manufacturing processes.

One task of ethics committees can also be to issue codes of conduct. Codes of conduct have the clear advantage that they are more detailed than just a general reference to ethical standards. These [5.] codes of conduct can be located both at [a.] EU or at [b.] national level. ${ }^{303}$

\footnotetext{
${ }^{293}$ Directive GMOs, Recital 58; emphases added.

${ }^{294}$ Directive GMOs, Art 29(1); emphasis added.

${ }^{295}$ EC recommendation 2008/345/EC of 7 February 2008 on a code of conduct for responsible nanosciences and nanotechnologies research, OJ 2008 L 116/46 [EC recommendation nanosciences], Annex, pt. 4.1.7.

${ }^{296}$ Council Directive 2013/59/Euratom of 5 December 2013 laying down basic safety standards for

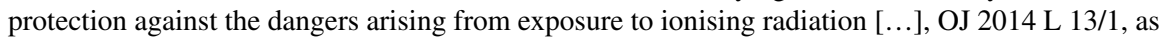
corrected by OJ 2016 L 72/69 [Directive ionising radiation], Art 55(2)(e).

${ }^{297}$ Regulation clinical trials, Art 2(2)(11); see also recital 18. For a comparison of the old and this new regime, see Frischhut (2015, p. 552).

${ }^{298}$ Regulation (EU) 2017/745 of 5 April 2017 on medical devices [...], OJ 2017 L 117/1 [Regulation medical devices], Art 2(56).

${ }^{299}$ Regulation (EU) 2017/746 of 5 April 2017 on in vitro diagnostic medical devices [...], OJ 2017

L 117/176 [Regulation in vitro medical devices], Art 2(59).

${ }^{300}$ Emphases added.

${ }^{301}$ Regulation clinical trials, Art 4 (et passim).

${ }^{302}$ Regulation medical devices, Art 62(3), et passim; Regulation in vitro medical devices, Art 58(3), et passim.

${ }^{303}$ In Council decision Albania, Annex, pt. 3.1., we find reference to a "code of ethics for the prisons system"; see also Directive (EU) 2016/1629 of 14 September 2016 laying down technical requirements for inland waterway vessels [...], OJ 2016 L 252/118, as amended by OJ 2018 L 174/15,
} 
At [5.a.] EU level we find the already mentioned "Code of Conduct for responsible nanosciences and nanotechnologies research". ${ }^{304}$ This code is quite detailed, comprising, amongst others, the principles of comprehensibility, respect of fundamental rights, the well-being of individuals and society, sustainability, the precautionary principle, inclusiveness (openness, transparency, and access to information), excellence, innovation, and accountability. ${ }^{305}$ Hence, ethics is only part of the general principles mentioned therein.

In the case of 'Directive Services', we find a provision, which encourages "the setting up of codes of conduct, in particular, by professional bodies, organisations and associations at [EU] level". Similar to the case of the example of nanosciences, this code of conduct is also not only about (professional) ethics. ${ }^{306}$

Again at EU level, we find a non-binding recommendation, the already mentioned European Charter for Researchers, which, apart from referring to recognized ethical principles and so forth, also requires researchers to "adhere to [...] ethical standards as documented in the different national, sectoral or institutional codes of ethics". 307 It therefore does not create a code of conduct, but just refers to existing ones, also [5.b.] at national level.

Besides examples of non-binding recommendations, we also find an obligation for the MS regarding the transposition of EU directive against child pornography, according to which MS have to undertake preventive action "such as the drawing up and reinforcement of a code of conduct and self-regulatory mechanisms in the tourism industry, the setting-up of a code of ethics" and so forth. ${ }^{308}$ Although the transposition of the directive into national law is binding in itself, thus the MS enjoy some flexibility as regards the form and methods of achieving this goal.

After ethics committees and codes of conduct, the substance of a reference to ethics can also be determined via references to [6.] other (international) documents.

In the context of the already mentioned three related examples of 'clinical trials',309 'medical devices' 310 and 'in vitro diagnostic medical devices', 311 reference is made to "the most recent version of the World Medical Association Declaration of

\footnotetext{
Annex VI, pt. 7 (“code of ethics”); Regulation financial rules, Art 136(2)(b) (“ethical standards of the profession").

${ }^{304} \mathrm{EC}$ recommendation nanosciences, Annex.

${ }^{305}$ Ibid. Annex, pt. 3.

${ }^{306}$ Directive services, recital 114. Recital 113 is also about ethics, however in this case those codes of conduct (drawn up by "interested parties" at EU level) are only mentioned insofar as they have to be "compatible with legally binding rules governing professional ethics and conduct in the Member States".

${ }^{307}$ EC Charter researchers, Annex, Section 1.

${ }^{308}$ Directive 2011/93/EU of 13 December 2011 on combating the sexual abuse and sexual exploitation of children and child pornography [...], OJ 2011 L 335/1, as corrected by OJ 2012 L18/7 [Directive combating abuse], recital 33.

${ }^{309}$ Regulation clinical trials, recitals 43 and 80 . The reference from ethics to the Helsinki declaration is an indirect one, via the notion of "good clinical practice", Art 2(2)(30).

${ }^{310}$ Regulation medical devices, recital 64.

${ }^{311}$ Regulation in vitro medical devices, recital 66.
} 
Helsinki on Ethical Principles for Medical Research Involving Human Subjects". 312 This Helsinki Declaration ${ }^{313}$ has the advantage not only of having been elaborated at a 'worldwide' basis, but also of providing relatively detailed rules as regards ethical behaviour. Of course, it has to be acknowledged that EU law can only refer to such detailed guidelines if they exist and have been elaborated by an acknowledged body in the relevant field. ${ }^{314}$

'Regulation in vitro medical devices' replaces the previous directive in this field, which for ethical requirements in the context of the removal, collection and use of tissues, cells and substances of human origin, has referred to the Council of Europe's Oviedo convention. ${ }^{315,316}$

It is also worth mentioning the example of the directive on statutory audits, which requires adherence to "highest ethical standards". ${ }^{317}$ In this context, it is the Commission's task to “adopt implementing measures on professional ethics as minimum standards [and when] doing so, it might consider the principles contained in the International Federation of Accountants (IFAC) Code of Ethics". 318 Thus, the Commission is invited to consider this international code.

Finally, yet importantly, there is also one example, where in the context of biocidal products reference is made to "internationally accepted ethical standards", without further guidance of how these standards are defined. ${ }^{319}$

After ethics committees, codes of conduct, and the determination via references to other (international) documents, we finally come to a category, where some information concerning the content or understanding of ethics can be found [7.] in the relevant legal document itself.

\footnotetext{
${ }^{312}$ Ibid. See also Directive 2001/83/EC of 6 November 2001 on the Community code relating to medicinal products for human use, OJ $2001 \mathrm{~L}$ 311/67, as amended by OJ 2017 L 238/44 [Directive medicinal products], Annex I, recital 8: "ethical principles that are reflected, for example, in the Declaration of Helsinki". For further examples, see Frischhut (2015, p. 554).

${ }^{313}$ World Medical Association, WMA Declaration of Helsinki, https://www.wma.net/policies-post/ wma-declaration-of-helsinki-ethical-principles-for-medical-research-involving-human-subjects/.

${ }^{314}$ On some criticism concerning the Helsinki Declaration, see: Ehni and Wiesing (2018).

${ }^{315}$ Convention for the protection of Human Rights and Dignity of the Human Being with regard to the Application of Biology and Medicine: Convention on Human Rights and Biomedicine (adopted 4 April 1997, entered into force 1 December 1999), ETS No164.

${ }^{316}$ Directive 98/79/EC of 27 October 1998 on in vitro diagnostic medical devices, OJ 1998 L 331/1, repealed (as of 26.05.2022) by OJ 2017 L 117/176 (= Regulation in vitro medical devices) [Directive in vitro medical devices], Art 1(4).

${ }^{317}$ Directive statutory audits, recital 9 .

${ }^{318}$ Ibid.

${ }^{319}$ Regulation (EU) No 528/2012 of 22 May 2012 concerning the making available on the market and use of biocidal products, OJ 2012 L 167/1, as amended by OJ 2017 L 121/45, Annex IV, 1.1.3.
} 
In the field of statutory audit, when mentioning "ethical and independence requirements", etc., the relevant provision on quality assurance of this regulation refers both to other chapters of the same regulation (as well as to another legal document ${ }^{320}$ ). ${ }^{321}$

Another example of determination of content in the relevant legal document itself can be found in the field of mining. While "ethical mining" is not explicitly defined, a systematic interpretation of the whole directive on supply chain due diligence obligations clearly refers to the affected region ("in particular in the African Great Lakes Region"), to the goods of import in question (gold, etc.), as well as the reasons of concern (conflicts, child labour, sexual violence, the disappearance of people, etc.). All this exhibits why the mining of these goods in these circumstances is deemed wrong. ${ }^{322}$

In the context of placing of proprietary medicinal products on the market, we find an example of a clear statement what is seen as unethical and what should be the consequences. "Since a full placebo comparison will not often be feasible or ethically acceptable in convulsive epilepsy, it is important in the later phases of evaluation to carry out controlled (randomized) clinical trials [...]".323

In addition, in the field of medicinal products for human use we find some thoughts on the treatment of control groups against the background of ethical considerations. "[T]hus it may, in some instances, be more pertinent to compare the efficacy of a new medicinal product with that of an established medicinal product of proven therapeutic value rather than with the effect of a placebo". ${ }^{324}$ The same directive also exempts applicants from certain documentation if "it would be contrary to generally accepted principles of medical ethics to collect such information". 325

In Horizon 2020 actions, falling within the scope of 'Regulation participation Horizon 2020' should 'be in conformity [...] with ethical principles, which include avoiding any breach of research integrity". ${ }^{326}$ In addition, Art 19 (entitled "Ethical principles") of 'Regulation establishing Horizon 2020', after stipulating that "[a]ll the research and innovation activities carried out under Horizon 2020 shall comply with ethical principles [and human rights]", excludes the following fields of research from

\footnotetext{
${ }^{320}$ Directive statutory audits.

${ }^{321}$ Regulation (EU) No 537/2014 of 16 April 2014 on specific requirements regarding statutory audit of public-interest entities [...], OJ 2014 L 158/77, as corrected by OJ 2014 L 170/66, Art 26(7)(a).

${ }^{322}$ Regulation (EU) 2017/821 of 17 May 2017 laying down supply chain due diligence obligations for Union importers of tin, tantalum and tungsten, their ores, and gold originating from conflictaffected and high-risk areas, OJ 2017 L 130/1 [Regulation supply chain], recital 23. On these transparency requirements, see Härkönen (2018).

${ }^{323}$ Council Recommendation 87/176/EEC of 9 February 1987 concerning tests relating to the placing on the market of proprietary medicinal products, OJ 1987 L 73/1 [Council Recommendation proprietary medicinal products], Annex IX, pt. 6. To some extent, this example could also be seen as a 'supportive argument'. It should be mentioned that other references in this document to ethics remain undetermined.

${ }^{324}$ Directive medicinal products, Annex I, part I, 5.2.5.1.

${ }^{325}$ Ibid. Annex I, Part II, 6.

${ }^{326}$ Recital 9.
} 
funding: "human cloning for reproductive purposes", "genetic heritage of human beings", as well as "research activities intended to create human embryos solely for the purpose of research or for the purpose of stem cell procurement, including by means of somatic cell nuclear transfer". ${ }^{327}$ This can be seen as a European consensus with regard to bioethics, although one could argue that this provision is 'only' about funding and not about the legality of these activities.

Although this book is based on a broad understanding of bioethics, the examples mentioned so far always referred to humans. Nonetheless, there are also examples where the beneficiaries of ethical or moral principles are not humans, but animals, plants or the environment. ${ }^{328}$ Especially animals are protected by ethical principles in different fields.

Bearing some resemblance to human dignity, the directive on the protection of animals used for scientific purposes asserts that animals "have an intrinsic value which must be respected". ${ }^{329}$ As a practical consequence arising from this approach, "animals should always be treated as sentient creatures and their use in procedures should be restricted to areas which may ultimately benefit human or animal health, or the environment", and their use "for scientific or educational purposes should therefore only be considered where a non-animal alternative is unavailable". ${ }^{330}$ This directive provides even more detailed statements with respect to the practical consequences of the 'intrinsic value' of animals, as there are restrictions for the use of non-human primates. ${ }^{331}$ Due to ethical considerations, the directive also sets a maximum threshold of permissible pain and therefore prohibits "the performance of procedures that result in severe pain, suffering or distress, which is likely to be long-lasting and cannot be ameliorated". 332

Apart from this directive, ethical considerations concerning animals are also the reason why mass slaughtering has been declared as being, amongst other things, "ethically questionable", 333 or, why there can even be "an ethical duty to kill pro-

\footnotetext{
${ }^{327}$ Art 19(3).

${ }^{328} \mathrm{EC}$ recommendation nanosciences, Annex, 3.2: "not harm or create a biological, physical or moral threat to people, animals, plants or the environment, at present or in the future".

${ }^{329}$ Directive 2010/63/EU of 22 September 2010 on the protection of animals used for scientific purposes, OJ 2010 L 276/33 [Directive animals], recital 12; emphasis added; and further refers to "the ethical concerns of the general public as regards the use of animals in procedures".

${ }^{330}$ Ibid; emphasis added.

${ }^{331}$ Directive animals, recital 17: "Due to their genetic proximity to human beings and to their highly developed social skills, the use of non-human primates in scientific procedures raises specific ethical and practical problems in terms of meeting their behavioural, environmental and social needs in a laboratory environment"; emphases added.

${ }^{332}$ Directive animals, recital 23. All those ethical considerations have to be taken into account for project evaluation; recital 38; Art 38(2)(d).

${ }^{333}$ Court of Auditors, Special Report No 1/2000 on classical swine fever, together with the Commission's replies, OJ $2000 \mathrm{C} 85 / 1$, para 18: "mass slaughtering is expensive, ethically questionable, wasteful of food resources and may destroy genetically valuable animals".
} 
ductive animals which are in severe pain where there is no economically viable way to alleviate such pain". 334

After a mere declaration annexed to the Maastricht Treaty ${ }^{335}$ and a protocol annexed to the Amsterdam Treaty, ${ }^{336}$ Art 13 TFEU now entails a horizontal clause according to which both the EU and the MS shall "pay full regard to the welfare requirements of animals", because animals are "sentient beings" ${ }^{337}$ In Horizon 2020, this Art 13 TFEU is addressed in the context of respect for "fundamental ethical principles" with the practical consequence that "the use of animals in research and testing should be reduced, with a view ultimately to replacing their use". 338

Leaving the field of bioethics, the already mentioned directive on statutory audits provides another example pertaining to this category where some understandings of the practical consequences of ethics are provided. After stating that statutory auditors should adhere to "the highest ethical standards", the directive provides that they should be "subject to professional ethics, covering at least their public-interest function, their integrity and objectivity and their professional competence and due care" ${ }^{339}$; further details have to be implemented by the MS. ${ }^{340}$

In the following example, ethics is not determined by the EU, MS and so forth on a collective basis, but by a single business entity. According to the Regulation on European social entrepreneurship funds, so called "[q]ualifying social entrepreneurship funds should invest in a manner consistent with their ethical investment strategy, for instance they should not undertake investments that finance the weapons industry, that risk breaches of human rights or that entail electronic waste-dumping". 341

\footnotetext{
${ }^{334}$ Council Regulation (EC) No 1099/2009 of 24 September 2009 on the protection of animals at the time of killing, OJ 2009 L 303/1, as amended by OJ 2018 L 122/11, recital 12.

${ }^{335}$ OJ 1992 C 191/103.

${ }^{336}$ OJ 1997 C 340/110.

${ }^{337}$ As protocols also pertain to EU primary law, the transfer from protocol to Treaty provision had more of a symbolic than a legal significance. Neither the declaration nor the protocol had entailed the rationale that animals are sentient beings.

${ }^{338}$ Regulation establishing Horizon 2020, recital 29. Similar in Council Regulation (Euratom) No 1314/2013 of 16 December 2013 on the Research and Training Programme of the European Atomic Energy Community (2014-2018) complementing the Horizon 2020 Framework Programme for Research and Innovation, OJ 2013 L $347 / 948$ [Regulation Horizon 2020 Euratom], recital 18 (N.B. This regulation will be repealed by Council Regulation (Euratom) 2018/1563 of 15 October 2018 on the Research and Training Programme of the European Atomic Energy Community (2019-2020) complementing the Horizon 2020 Framework Programme for Research and Innovation, and repealing Regulation (Euratom) No 1314/2013, OJ 2018 L 262/1). Animal welfare "and other ethical issues" are also addressed in Council Decision 2013/743/EU of 3 December 2013 establishing the specific programme implementing Horizon 2020 - the Framework Programme for Research and Innovation (2014-2020) [...], OJ 2013 L 347/965, as corrected by OJ 2015 L 102/96, Annex I, Part III, 2.2.3.

${ }^{339}$ Directive statutory audits, recital 9 .

${ }^{340}$ Directive statutory audits, Art 21(1).

${ }^{341}$ Regulation 346/2013/EU of 17 April 2013 on European Social Entrepreneurship Funds, OJ 2013 L 115/18, as amended by OJ 2017 L 293/1, recital 21; emphases added.
} 
The combined approach of the ECB, that is to say an Ethics Officer plus principles (such as avoidance of conflicts of interest, confidentiality, transparency and openness, etc.) contained in a code of conduct, has already been mentioned. ${ }^{342}$ Likewise, the European Anti-Fraud Office (OLAF) merely follows a substantive approach for their Supervisory Committee. Art 4, entitled 'ethics', requires the members to act independently, neither seeking nor taking instructions from others, not to deal with matters where they have a personal interest, to demonstrate confidentiality, and to adhere to an obligation of notification if any such situation occurs. ${ }^{343}$

In an indirect way, we can also add examples, where reference is made to notions that have a pre-determined meaning from another field, such as public morality, ${ }^{344}$ which has been shaped by the CJEU, ${ }^{345}$ or moral hazard, ${ }^{346}$ as a notion of microeconomics. ${ }^{347}$ The example of moral hazard also derives from the financial crisis, where the Commission's banking communication refers several times to 'moral hazard' 348 In a similar way as for international agreements, moral hazard is addressed in the context of burden sharing. ${ }^{349}$ This concept can be explained by referring to a situation caused by the immoral behaviour of a single body that is dangerous for a bigger group (society). Most people would agree to qualify the risky behaviour of certain banks to the detriment of taxpayers (whereas bonuses would still be paid, maybe also with the help of those taxpayers' subsidies) as immoral. ${ }^{350}$

After having seen determination by ethics committees, codes of conduct, references to international documents and further information provided by EU law itself, we finally arrive at the last category, that is, EU law, where ethics [8.] remains undetermined.

The example of patient mobility has already been mentioned in the category of 'non-interference', where patients do not have a right to cross-border healthcare because the directive shall not "undermine the fundamental ethical choices of Member States". ${ }^{351}$ This undetermined provision can have a significant impact on patients seeking cross-border healthcare. In fact, some MS feared the application of

\footnotetext{
${ }^{342}$ Supra at note 283.

${ }^{343}$ OLAF Rules of Procedure of the OLAF Supervisory Committee, OJ 2011 L 308/114.

${ }^{344}$ Regulation (EU) 2015/478 of 11 March 2015 on common rules for imports, OJ 2015 L 83/16, Art 24(2)(a).

${ }^{345}$ See supra Sects. 3.1.1 and 3.3.1.1.

${ }^{346}$ Directive 2014/59/EU of 15 May 2014 establishing a framework for the recovery and resolution of credit institutions and investment firms [...], OJ 2014 L 173/190, as completed by OJ 2018 L $67 / 8$, recital 45.

${ }^{347}$ See supra at note 89.

${ }^{348}$ EC communication on the application, from 1 August 2013, of State aid rules to support measures in favour of banks in the context of the financial crisis ('Banking Communication'), OJ $2013 \mathrm{C}$ 216/1, paras 15, 40, 77 and 84. In this context, see e.g. OJ 2015 L 80, 1 and 49.

${ }^{349}$ Ibid. para 15; emphases added.

${ }^{350}$ For a good description, see Sandel (2010, pp. 12-13).

${ }^{351}$ Directive patient mobility, recital 7. Recital 53 also states that the principle of "recognition of prescriptions from other Member States should not affect any professional or ethical duty that would require pharmacists to refuse to dispense the prescription"; see also Art 11(1)(3).
} 
this directive to sensitive issues "like euthanasia, DNA-testing or IVF". ${ }^{352}$ Contrary to what one would expect, it was not the Council of Ministers but the EP that at a very early stage of the legislative procedure, proposed amendments making clear that "[n]o provision of this Directive should be interpreted in such a way as to undermine the fundamental ethical choices of Member States". 353 This was strengthened by emphasizing that "[n]otwithstanding those common values it is accepted that Member States take different decisions on ethical grounds as regards the availability of certain treatments and the concrete access conditions [and that this] Directive is without prejudice to ethical diversity". ${ }^{354}$ The question remains, as to whether this provision has to be interpreted in a narrow sense, as it requires 'fundamental' ethical choices. Moreover, only the legal materials help to shed more light on the void of this undetermined concept.

While this example refers to the MS to determine ethics in this regard, the following examples provide no information whatsoever on the understanding behind the term of ethics used in those documents, of both a binding and non-binding nature.

One example of a binding nature is about food law, where it has been acknowledged that scientific risk assessment alone might not provide all necessary information for, but where also "societal, economic, traditional, ethical and environmental factors" have to be considered. ${ }^{355}$ The reference to ethics might be very general (one factor amongst others to be taken into account), but does not mitigate the fact that the concept of ethics remains undetermined.

Other examples of non-determined references to ethics are as follows ${ }^{356}$ : "scientific ethics", 357 "relevant ethical principles", 358 "business ethics standards",359 "professional ethics", 360 "ethical principles, which include avoiding any breach of research integrity", ${ }^{361}$ or "environmental and ethical considerations". ${ }^{362}$ In another

\footnotetext{
${ }^{352}$ Van Hoof and Pennings (2012, p. 194).

${ }^{353} \mathrm{EP}$ legislative resolution of 23 April 2009 on the proposal for a directive on the application of patients' rights in cross-border healthcare, OJ 2010 C 184E/368, recital 6.

${ }^{354}$ Ibid. recital 14; emphases added.

${ }^{355}$ Regulation (EC) No 178/2002 of 28 January 2002 laying down the general principles and requirements of food law, establishing the European Food Safety Authority and laying down procedures in matters of food safety, OJ 2002 L 31/1, as amended by OJ 2017 L 117/1, recital 19.

${ }^{356}$ Emphases added.

${ }^{357}$ Regulation data fisheries, Art 20(1)(c).

${ }^{358}$ EC Regulation (EU) 2015/445 of 17 March 2015 amending Regulation (EU) No 1178/2011 as regards technical requirements and administrative procedures related to civil aviation aircrew, OJ 2015 L 74/1, Annex IV.

${ }^{359}$ Directive (EU) 2016/97 of 20 January 2016 on insurance distribution (recast), OJ 2016 L 26/19, as amended by OJ 2018 L 76/28, Annex I.

${ }^{360}$ Directive (EU) 2018/958 of 28 June 2018 on a proportionality test before adoption of new regulation of professions, OJ 2018 L 173/25, recitals 27 and 30, Art 7(3)(c).

${ }^{361}$ Decision (EU) 2017/1324 of 4 July 2017 on the participation of the Union in the Partnership for Research and Innovation in the Mediterranean Area (PRIMA) jointly undertaken by several Member States, OJ 2017 L 185/1, recital 8.

${ }^{362}$ EC decision (EU) 2018/813 of 14 May 2018 on the sectoral reference document on best environmental management practices, sector environmental performance indicators and benchmarks of
} 
reference to "ethical or environmental reasons", 363 this regulation further refers to another document, ${ }^{364}$ but without further clarification on the determination of ethics. In addition, the new General Data Protection Regulation (GDPR) ${ }^{365}$ refers to "recognised ethical standards for scientific research", 366 as well as "ethics for regulated professions". ${ }^{367}$ Besides ethics, in the field of trademark, we find a reference to "accepted principles of morality" in both the corresponding EU directive ${ }^{368}$ and regulation. ${ }^{369,370}$

Another example refers to the European Council, ${ }^{371}$ which expressed in its Stockholm presidency conclusions from 2001 the need to "strengthen the European biotechnology sector's competitiveness", while ensuring that this is "consistent with common fundamental values and ethical principles". 372 Some could take the view that there is no need for a (purely) political document to provide detailed statements, nonetheless, also in this case we lack further guidance as to the understanding of ethics.

The Council (of Ministers) resolution concerning fundamental health policy choices is another example of a non-binding document, taking 'only' note of some topics, "which warrant joint consideration", such as "revision of medical studies syllabuses in order to incorporate the relevant economic, legal, ethical and social aspects necessary to ensure that practitioners dispense adequate health care". ${ }^{373}$ This example is comparable to the one of port State inspectors, where the content of ethics as part of a training programme is not determined. ${ }^{374}$ Although there is no

excellence for the agriculture sector under Regulation (EC) No 1221/2009 on the voluntary participation by organisations in a Community eco-management and audit scheme (EMAS), OJ $2018 \mathrm{~L}$ 145/1, Annex (passim).

${ }^{363}$ EC Regulation (EU) 2016/246 of 3 February 2016 amending Annex I to Regulation (EC) No $794 / 2004$ as regards the forms to be used for the notification of State aid in the agricultural and forestry sectors and in rural areas, OJ 2016 L 51/1, Annex (on p. 78).

${ }^{364}$ European Union Guidelines for State aid in the agricultural and forestry sectors and in rural areas 2014-2020, OJ 2014 C 204/1.

${ }^{365}$ Regulation (EU) 2016/679 of 27 April 2016 on the protection of natural persons with regard to the processing of personal data and on the free movement of such data [...] (General Data Protection Regulation), OJ 2016 L 119/1, as corrected by OJ 2018 L 127/2 [Regulation GDP].

${ }^{366}$ Ibid. recital 33.

${ }^{367}$ Ibid. recital 73, Art 23(1)(g).

${ }^{368}$ Directive (EU) 2015/2436 of 16 December 2015 to approximate the laws of the Member States relating to trade marks, OJ 2015 L 336/1, as corrected by OJ 2016 L 110/5, Art 4(1)(f) and Art 31(1).

${ }^{369}$ Regulation (EU) 2017/1001 of 14 June 2017 on the European Union trade mark, OJ 2017 L 154/1, Art 7(1)(f), Art 76(1) and Art 85(1).

${ }^{370}$ On the diversity argument when applying this concept to the figurative trademark 'La Mafia', see Sect. 3.3.1.2.

${ }^{371}$ Art 15 TEU.

${ }^{372}$ Presidency Conclusions, Stockholm European Council (23./24.3.2001), part I, VI. 44.

${ }^{373}$ Resolution of the Council [etc.] of 11 November 1991 concerning fundamental health-policy choices, OJ 1991 C304/5.

${ }^{374}$ Supra at note 61. 
further information on what constitutes an ethical syllabus, the MS competence ${ }^{375}$ for both education and health might be the legally based reason why this non-legal term should be defined by the MS.

The same idea can hold true for other health related (non-binding) documents in the context of cancer screening ${ }^{376}$ and hereditary illnesses ${ }^{377}$ on the one hand, and for lifelong learning ${ }^{378}$ on the other.

Within the shared competence of the internal market, ${ }^{379}$ we find one example of a task in the public interest, which is about "doctors or veterinary bodies ensuring that their members conform to ethical or sanitary rules". ${ }^{380}$ This example adds up to our list of undetermined references to ethics, where a possible solution could be to see those bodies in charge of defining those ethical rules.

\subsubsection{Conclusion}

Unethical behaviour can have an impact, both when seeking an authorisation or in the context of research funding. Given the amount of documents that have to be published in the 24 official languages, the inconsistencies identified in this chapter are a minor issue. Nevertheless, it makes a difference whether a document refers to ethics or morality (Directive greenhouse gas emissions), or to ethical or moral principles recognised in one or more MS (Directive Biotech).

Beneficiaries have mainly been humans, however, also animals are protected due to arguments reminding us of 'human dignity'. In order to achieve ethical behaviour, training plays an important role. Therefore, it is no surprise, that also in case of 'EU reference centres for animal welfare' we find the requirement of "suitably qualified staff with adequate training [...] in ethical issues related to animals". ${ }^{381}$ In a completely different field, the importance of "[i]ncreased awareness of [...] ethical issues among students and their teachers" 382 is also emphasized.

\footnotetext{
${ }^{375}$ Art 6(a) and (e) TFEU.

${ }^{376}$ Council Recommendation of 2 December 2003 on cancer screening, OJ 2003 L 327/34, recital 10.

${ }^{377}$ Conclusions of the Council [etc.] of 15 May 1992 on hereditary illnesses, OJ 1992 C 148/3, recital 5 .

${ }^{378}$ Council Recommendation of 22 May 2018 on key competences for lifelong learning, OJ 2018 C 189/1, Annex (passim).

${ }^{379}$ Art 4(2)(a) TFEU.

${ }^{380} \mathrm{EC}$ recommendation of 26 March 2009 on data protection guidelines for the Internal Market Information System (IMI), OJ 2009 L 100/12, Annex, pt. 6 II.

${ }^{381}$ Regulation (EU) 2017/625 of 15 March 2017 on official controls and other official activities performed to ensure the application of food and feed law, rules on animal health and welfare, plant health and plant protection products [...], OJ 2017 L 95/1, as corrected by OJ 2017 L 137/40, Art 95(3)(c).

${ }^{382}$ Council Decision (CFSP) 2016/51 of 18 January 2016 in support of the Biological and Toxin Weapons Convention (BTWC) in the framework of the EU Strategy against Proliferation of Weapons of Mass Destruction, OJ 2016 L 12/50, Annex, pt. 1.6.2.
} 
Concerning humans, special groups that have not been mentioned so far, are incapacitated subjects ${ }^{383}$ in respect of clinical trials on medicinal products for human use, as well as children, ${ }^{384}$ where specific ethical concerns might arise and should be addressed.

The numerous EU documents referring to ethics and morality can be clustered in the above-mentioned, inductively developed, categories. It has to be emphasized that some examples are overlapping and, hence, could fall in various categories.

The category of ethics serving as a [1.] 'protection shield' clearly is not a very ambitious approach. Using ethics as [2.] a supportive argument is clearly less of a problem, as the legal situation (which it defends) should be able to be self-standing. It is also less of a problem, when ethics is determined by [4.] an ethics committee or via a [5.] code of conduct, in either category either at EU or at national level. Sufficient clarification with regard to the content of references to ethics can also be guaranteed via references to [6.] other (international) documents, such as the Helsinki declaration or the Oviedo convention, or if further information [7.] is provided in the relevant EU document itself.

From the perspective of legal certainty, a [3.] parallel ethical and legal assessment (e.g. Directive Biotech), can be problematic if the criteria for this ethical assessment are not clearly stated, which finally leads us to category [8.], where ethics remains undetermined.

The examples we have seen in the category of ethics committees clearly displays that ethics plays a role in sensitive fields: this is the case for 'science and new technologies' (EGE), in the financial field, in data protection and digitalization, or in the health sector (e.g. clinical trials, medical devices and in vitro diagnostic medical devices). Further recent examples of sensitive fields referring to ethics can be found in the context of 'health in the digital society', 385 'artificial intelligence', 386 'robotics', 387 and 'digital ethics'. 388

\footnotetext{
${ }^{383}$ Regulation clinical trials, Art 10(2).

${ }^{384}$ Council Recommendation proprietary medicinal products, Annex XIV, pt. 3.2.2(b); Council Resolution of 14 December 2000 on paediatric medicinal products, OJ $2001 \mathrm{C} 17 / 1$, recitals 7 and 9; Regulation clinical trials, Art 10(1).

${ }^{385}$ Council conclusions on Health in the Digital Society - making progress in data-driven innovation in the field of health, OJ 2017 C 440/3, pt. 23 ("ethical aspects and the differences in digital and health literacy").

${ }^{386} \mathrm{EC}$ 'EU MS sign up to cooperate on Artificial Intelligence' (10.4.2018), https://ec.europa.eu/ digital-single-market/en/news/eu-member-states-sign-cooperate-artificial-intelligence.

${ }^{387}$ EP resolution of 16 February 2017 with recommendations to the Commission on Civil Law Rules on Robotics, P8_TA(2017)0051 [EP resolution robotics], passim (50 mentions); the importance of values in the context of robots has also been stressed by Sahlin $(2018$, p. 85$)$.

${ }^{388}$ Ethics Advisory Group (2018). See also: Executive summary of Opinion No 4/2015 of the European Data Protection Supervisor, 'Towards a new digital ethics: Data, dignity and technology', OJ 2015 C 392/9.
} 


\subsubsection{The Ethical Spirit in Implementing EU Directives}

Some of these documents of EU secondary and tertiary law are EU directives, which need to be implemented into national law. ${ }^{389}$ The national provisions implementing these directives in the various MS, are well documented in EUR-Lex, respectively in the relevant national legal databases. 390

This chapter is related to objective 2, i.e. the question how selected MS have dealt with ethics and morality in the way they have implemented these directives. More precisely: how have these countries implemented the selected EU-Directives regarding ethics and/or morality into national law? In implementing these directives, have they also referred to ethics and/or morality, respectively to similar concepts and related terms, such as EU values and human or fundamental rights? Finally, can we conclude on an 'ethicalization' of national law via EU law?

The countries examined are, in alphabetical order, Austria, the Czech Republic, France, Germany, Ireland, Italy, Slovakia, Spain, and the United Kingdom. While not all 28 Member States could be covered, this chapter covers the biggest Member States, plus taking into account different legal systems (common law, e.g. in the UK and Ireland; civil law system), old and new Member States, from Northern and Southern Europe, as well as from Western and Eastern Europe).

This chapter is based on a research project, which was conducted in two waves, based on a research design developed, as well as the project itself directed by the author, with several students involved. The first round in 2016 covered Austria and Germany, ${ }^{391}$ France, ${ }^{392}$ Ireland and the United Kingdom, ${ }^{393}$ as well as Spain, ${ }^{394}$ the second round, in 2017, Italy ${ }^{395}$ as well as the Czech Republic and Slovakia. ${ }^{396}$ Space precludes a discussion of the numerous findings of these two rounds. Therefore, the most important results are summarized in the following.

The 28 directives identified for this project mainly pertain to the field of health (see Table 3.2), addressing issues of bioethics. Therefore, the majority of references to these concepts can be found in the field of health, mainly referring to 'ethics', less to 'morality'.

As can also be seen from Fig. 3.2, the majority of these 28 directives analysed have been adopted since 2001, which has to be seen against the background of the creation of the EGE in December 1997. ${ }^{397}$ While the first directives pertain to the

\footnotetext{
${ }^{389}$ Art 288(3) TFEU.

${ }^{390}$ That is why in Table 3.2 only those directives are indicated which have been mentioned elsewhere in this book.

${ }^{391}$ Hotarek (2016).

${ }^{392}$ Estermann (2016).

${ }^{393}$ Pacey (2016).

${ }^{394}$ Varona Martín (2016).

${ }^{395}$ Sava (2017).

${ }^{396}$ Kubincová (2017).

${ }^{397}$ See infra Sect. 4.2.1.
} 
Table 3.2 EU 'ethics directives', time frame and areas

\begin{tabular}{|c|c|c|c|c|c|c|}
\hline Time frame & Technology & Health & Employment & $\begin{array}{l}\text { Finance \& } \\
\text { accounting }\end{array}$ & $\begin{array}{l}\text { Children \& } \\
\text { animals }\end{array}$ & \\
\hline \multirow[t]{3}{*}{ 1990-1995 } & & $1990 / 385$ & & & & \\
\hline & & $1991 / 507$ & & & & \\
\hline & & $1993 / 42$ & & & & \\
\hline $1996-2000$ & $1998 / 44^{\mathrm{a}}$ & $1998 / 79^{b}$ & & & & \\
\hline \multirow{7}{*}{ 2001-2005 } & & $2001 / 18^{c}$ & \multirow[t]{7}{*}{$2005 / 36^{\mathrm{g}}$} & & & \\
\hline & & $2001 / 20^{\mathrm{d}}$ & & & & \\
\hline & & $2001 / 83^{e}$ & & & & \\
\hline & & $2003 / 63$ & & & & \\
\hline & & $2004 / 23^{\mathrm{f}}$ & & & & \\
\hline & & $2004 / 27$ & & & & \\
\hline & & $2005 / 28$ & & & & \\
\hline \multirow[t]{2}{*}{ 2006-2010 } & $2006 / 87$ & $2007 / 47$ & $2006 / 123^{i}$ & \multirow[t]{2}{*}{$2006 / 43^{j}$} & \multirow[t]{2}{*}{$2010 / 63^{k}$} & \\
\hline & $2009 / 30^{\mathrm{h}}$ & $2009 / 120$ & $2009 / 50$ & & & \\
\hline \multirow[t]{3}{*}{$2011-2015$} & & $2011 / 24^{1}$ & \multirow[t]{3}{*}{$2013 / 55$} & $2014 / 17$ & \multirow[t]{3}{*}{$2011 / 93^{n}$} & \\
\hline & & \multirow[t]{2}{*}{$2013 / 59^{\mathrm{m}}$} & & $2014 / 56$ & & \\
\hline & & & & $2014 / 65$ & & \\
\hline Number: & 3 & 15 & 4 & 4 & 2 & $\begin{array}{l}28 \\
\text { (in } \\
\text { total) }\end{array}$ \\
\hline
\end{tabular}

${ }^{\text {a Directive Biotech }}$

${ }^{\mathrm{b}}$ Directive in vitro medical devices

${ }^{\mathrm{c}}$ Directive GMOs

${ }^{\mathrm{d}}$ Directive clinical trials

${ }^{\mathrm{e}}$ Directive medicinal products

${ }^{f}$ Directive 2004/23/EC of 31 March 2004 on setting standards of quality and safety for the donation, procurement, testing, processing, preservation, storage and distribution of human tissues and cells, OJ 2004 L 102/48, as amended by OJ 2009 L 188/14 [Directive tissues and cells]

${ }^{\mathrm{g}}$ Directive recognition qualifications

${ }^{\mathrm{h}}$ Directive greenhouse gas emissions

${ }^{\mathrm{i}}$ Directive services

${ }^{\mathrm{j}}$ Directive statutory audits

${ }^{\mathrm{k}}$ Directive animals

${ }^{1}$ Directive patient mobility

${ }^{\mathrm{m}}$ Directive ionising radiation

${ }^{\mathrm{n}}$ Directive combating abuse 


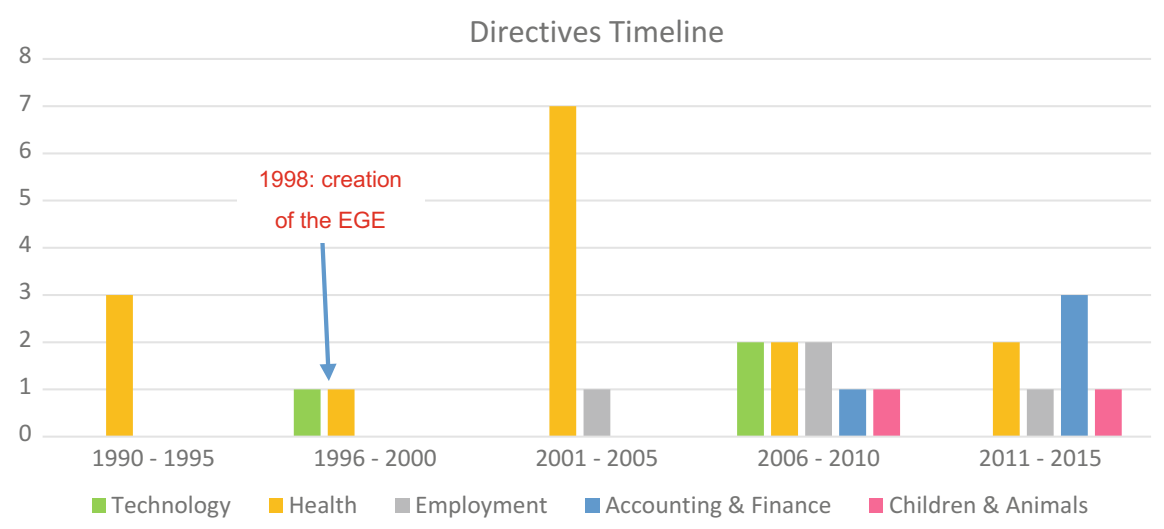

Fig. 3.2 EU 'ethics directives', timeline and areas (total numbers). Source Pacey (2016, p. 38)

field of health (which, in total, comprises more than half of these directives), since 2001 we can observe an expansion also to other areas.

These directives have been analysed with regard to the key terms of 'ethics', 'morality' and related terms. These terms plus the different areas, where they occur, can be seen below from Fig. 3.3. 'Ethics' and related terms occur most frequently, especially in the field of 'health', while 'professional ethics' pertains to the field of 'employment', as well as 'accounting \& finance'. This is followed by the concept of 'integrity', which primarily occurs in the area of 'accounting \& finance'. As mentioned above, the term of morality (primarily only in the field of 'technology') plays a minor role.

When taking a closer look at the term 'ethics' in its various breakdowns, one can see the following picture (see Fig. 3.4), which clearly exhibits, first of all, that the term 'ethics committee' prevails, and, second, that this term clearly pertains to the health field.

When, in a next step, we turn from these EU directives to the national level, the various findings of the national implementation measures (NIM) of the eight MS examined can be summarized as follows ${ }^{398}$ :

Although it might sound obvious, keywords in EU directives have only been implemented, when mentioned in those parts of a Directive which have to be implemented, i.e. articles, but not if only mentioned in the recitals of the preamble. ${ }^{399}$ For instance, references to fundamental rights or the EU's common values mainly occur in the preamble of directives, thus they play no major role in the NIM.

\footnotetext{
${ }^{398}$ Apart from the limitations specifically mentioned in the respective papers, the following should be mentioned here: firstly, it may be that a MS has not had to transpose all directives [due to an opt-out; see e.g. Pacey (2016, p. 41)] or, in breach of the EU law, at the time of the survey, has in fact not transposed them.

${ }^{399}$ E.g. Hotarek (2016, p. 43).
} 
Total Key Words in all Areas

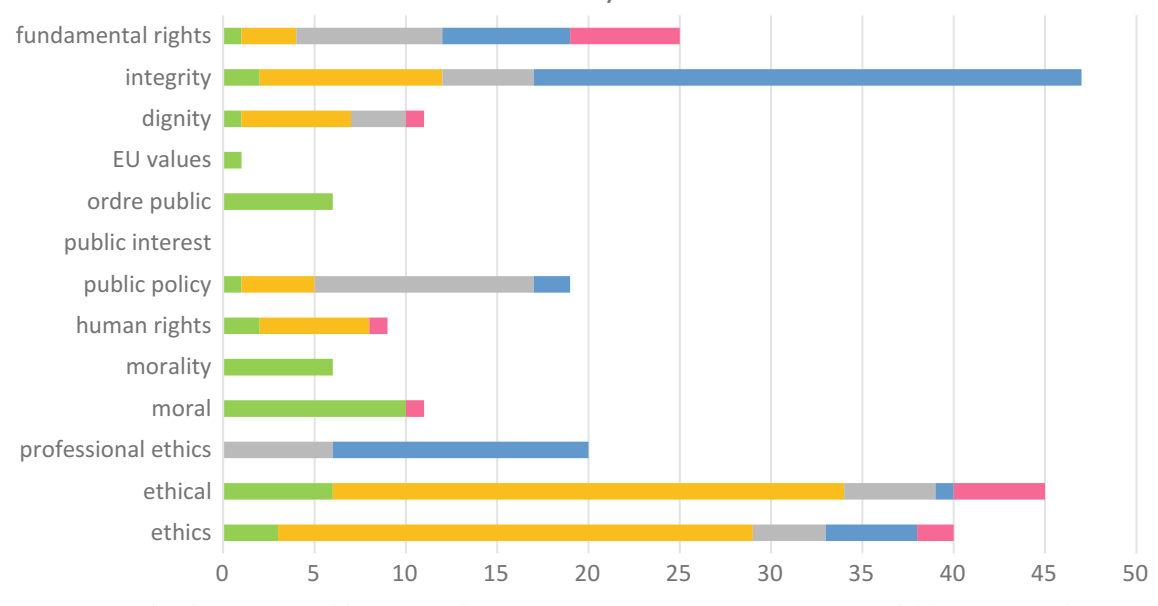

Technology Health Employment $\square$ Accounting \& Finance $\square$ Children \& Animals

Fig. 3.3 EU 'ethics directives', key terms in different areas (total numbers). Source Pacey (2016, A11)

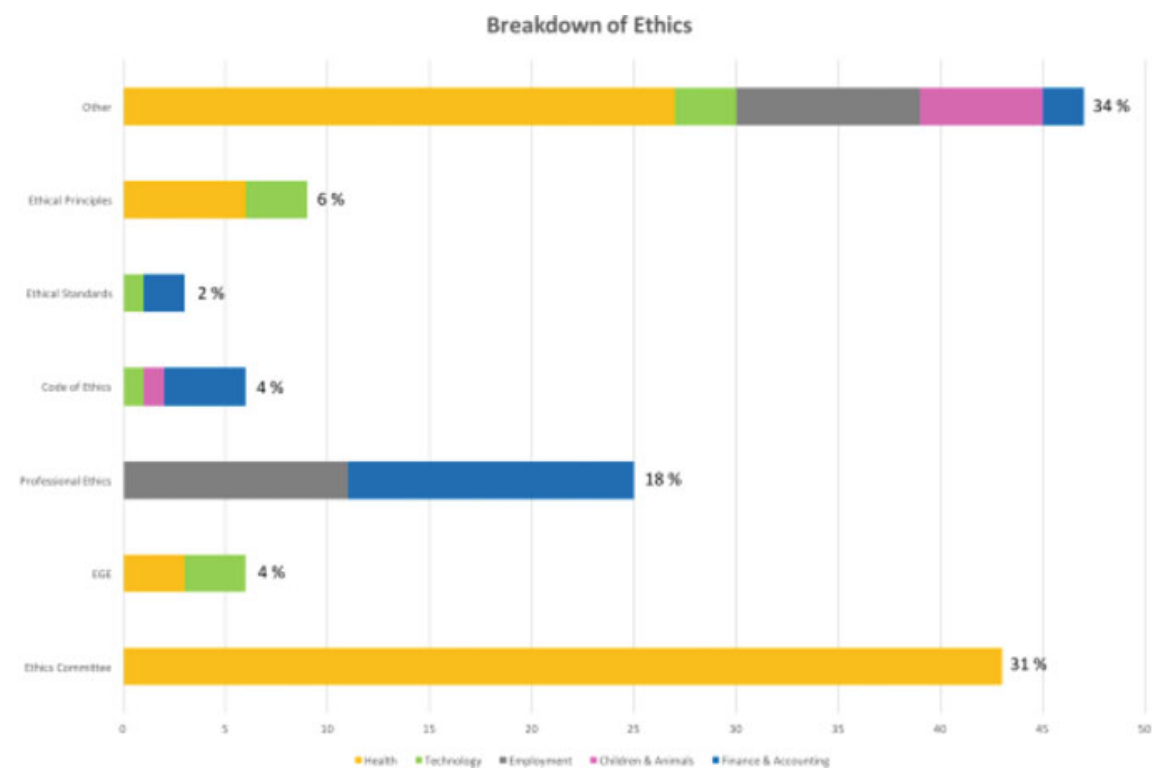

Fig. 3.4 Breakdown of 'ethics' in 'ethics directives' in different areas (percentage). Source Sava (2017, 34 and A20) 
To make a long story short, there are mainly two reasons why one has to be cautious with over-stressing a quantitative approach. ${ }^{400}$ First of all, the degree to which a country (e.g. France) refers to ethics and morality when implementing EU Directives is strongly linked to the pre-existing substantive (e.g. "les bonnes mours françaises") ${ }^{401}$ and procedural (e.g. since 1983: Comité Consultatif National d'Ethique, CCNE) approach to ethics and morality in this country. This might also explain the low ratio of NIM referring to keywords (e.g. 15.4\%). Second, although a country like Spain has a high number of references to key terms in its NIM, this might be due to the pragmatic 'copy-paste' approach, which, beside the text of the directives, also includes copy-pasting recitals and annexes. ${ }^{402}$ Thirdly, a large number of national provisions can implement one single directive, which can distort the validity of quantitative analyses..$^{403}$

Another interesting result could be identified by comparing the results of the different countries. The two waves of this research project revealed, that countries with comparable legal traditions also display similar results. That was true for Austria and Germany, ${ }^{404}$ for Ireland and the UK, ${ }^{405}$ as well as for the Czech Republic and Slovakia. ${ }^{406,407}$ The question of an 'ethicalization' of national law via these EU 'ethics directives' has to be answered in the sense of not playing a major role, as these legal traditions clearly have a higher impact. Again, we can identify an approach, which is not very ambitious, where MS mainly implement these 'ethics elements' of a directive, which are mandatory for them.

In a similar way as for the key terms identified in the directives, also the NIM mainly refer to ethics and especially 'ethics committees', primarily because of Directive clinical trials. ${ }^{408}$ This was, for instance, the case in Italy, were $73 \%$ of all terms related to ethics, were about 'ethics committees' ('comitato etico'), ${ }^{409}$ or in France, with the highest number of references to 'comité d'éthique', ${ }^{410}$ and the same for Austria and Germany. ${ }^{411}$

\footnotetext{
${ }^{400} \mathrm{~A}$ ranking of the amount of NIM in the various MS looks as follows: France: 402; Spain: 125; UK: 104; Austria: 102; Germany: 101; Czech Republic: 73; Slovakia: 61; Ireland: 59; Italy: 36.

${ }^{401}$ Estermann (2016, p. 54).

${ }^{402}$ Varona Martín $(2016,55,61)$.

${ }^{403}$ For instance, as in the case of the implementation of Directive patient mobility in Germany; Hotarek (2016, p. 44).

${ }^{404}$ Hotarek $(2016,36,46,48)$.

${ }^{405}$ Pacey (2016, p. 52).

${ }^{406}$ Kubincová $(2017,25,45)$.

${ }^{407}$ For instance, it can play a role if MS tend to amend existing laws (e.g. in the case of Austria and Germany; Hotarek (2016, p. 43)), or to create new ones.

${ }^{408}$ Now, Regulation clinical trials; see Sect. 1.2, notes 55 and 56.

${ }^{409}$ Sava $(2017,33$ and 43).

${ }^{410}$ Estermann (2016, p. 40).

${ }^{411} 220$ references to ethics committees (all of them in the field of health), that is to say, by far the highest number, followed by 28 for 'ethical', 27 for 'integrity' and 11 for 'ethics'; and quite the same result for Germany; Hotarek (2016, A15).
} 
Consequently, while some references to ethics, etc. were unavoidable in the sense that it was mandatory for the MS, we cannot observe a uniform 'ethicalization' via EU directives in these nine countries.

\section{References}

Arnull, A. (2014). Protocol (30) on the application of the charter of fundamental rights of the European Union to Poland and the United Kingdom. In S. Peers, T. K. Hervey, J. Kenner, \& A. Ward (Eds.), The EU charter of fundamental rights: A commentary (pp. 1595-1612). Oxford: Hart Publishing.

Bogdandy, A. V., Bogdanowicz, P., Canor, I., Taborowski, M., \& Schmidt, M. (2018). Guest Editorial: A potential constitutional moment for the European rule of law: The importance of red lines'. Common Market Law Review, 55, 983-995.

Bogdandy, A. V., \& Ioannidis, M. (2014). Systemic deficiency in the rule of law: What it is, what has been done, what can be done. Common Market Law Review, 51, 59-96.

Cohen, I. G. (2012). Circumvention tourism. Cornell Law Review, 97, 1309-1398.

Dawson, M., Witte, B. D., \& Muir, E. (Eds.). (2013). Judicial activism at the European Court of Justice. Cheltenham, Northampton Mass: Edward Elgar Publishing.

de Witte, F. (2013). Sex, drugs \& EU law: The recognition of moral and ethical diversity in EU law. Common Market Law Review, 50, 1545-1578.

Ehni, H.-J., \& Wiesing, U. (2018). Illegitmate authorship and flawed procedures: Fundamental, formal criticisms of the Declaration of Helsinki. Bioethics. Advance online publication. https:// doi.org/10.1111/bioe.12503.

Estermann, M. (2016). European law and ethics-implementation of EU directives referring to ethics and/or morality in France. Master thesis at MCI 'International Business \& Law', summer term 2016, Innsbruck.

Ethics Advisory Group. (2018). Towards a digital ethics: Report by the Ethics Advisory Group established by the European Data Protection Supervisor, the EU's independent data protection authority. Retrieved from https://edps.europa.eu/sites/edp/files/publication/18-01-25_eag_ report_en.pdf.

European Ombudsman. (2018). Annual report 2017. Strasbourg, Brussels: Publications Office of the EU.

Frischhut, M. (2015). "EU": Short for "Ethical" Union?: The role of ethics in European Union Law. Heidelberg Journal of International Law (HJIL), 75, 531-577.

Frischhut, M. (2017). Legal and ethical issues of cross-border reproductive care from an EU perspective: Chapter 17. In M. K. Smith \& L. Puczkó (Eds.), The Routledge handbook of health tourism (pp. 203-218). London, New York: Taylor \& Francis.

Grad, J., \& Frischhut, M. (2019). Legal and ethical rules in EU decision-making: "Soft law" for targets and actors of lobbying. In D. Dialer \& M. Richter (Eds.), Lobbying in the European Union: Strategies, dynamics and trends (pp. 305-327). Springer. Retrieved from https://doi.org/10.1007/ 978-3-319-98800-9_22.

Gruber, N. (2015). Ethics in the framework of European Union Law with special emphasis on International Agreements. Master thesis at MCI 'International Business \& Law', summer term 2015, Innsbruck.

Hall, C. M. (2013). Medical and health tourism: The development and implications of medical mobility. In C. M. Hall (Ed.), Medical tourism: The ethics, regulation, and marketing of health mobility (pp. 3-27). Abingdon, Oxon: Routledge.

Hamm, M. (2018). Transparency in the European crisis: Between ethicization and economicization. In F. Foret \& O. Calligaro (Eds.), European values: Challenges and opportunities for EU Governance (pp. 119-136). London: Routledge. 
Härkönen, E. (2018). Conflict minerals in the corporate supply chain: Is transparency the solution to human rights violations in the tantalum, tin, tungsten and gold supply chains? European Business Law Review, 29, 691-727.

Hatzopoulos, V. (2012). Regulating services in the European Union. Oxford: Oxford University Press.

Hermerén, G. (2008). European values - and others. Europe's shared values: Towards an ever-closer Union? European Review, 16, 373-385. https://doi.org/10.1017/S1062798708000318.

Hermerén, G. (2012). The principle of proportionality revisited: Interpretations and applications. Medicine, Health Care and Philosophy, 15, 373-382. https://doi.org/10.1007/s11019-011-9360$\mathrm{x}$.

Horsley, T. (2013). Reflections on the role of the Court of Justice as the "motor" of European integration: Legal limits to judicial lawmaking. Common Market Law Review, 50, 931-964.

Hotarek, T. (2016). EU law and ethics-implementation of EU directives referring to ethics and/or morality in Austria and Germany. Master thesis at MCI 'International Business \& Law', summer term 2016, Innsbruck.

James, H. S., Jr. (2008). Asymmetric Information. In R. W. Kolb (Ed.), Encyclopedia of business ethics and society (pp. 123-125). Los Angeles, London, New Delhi, Singapore: Sage Publications.

Kubincová, M. (2017). EU law and ethics: Implementation of European Union directives referring to ethics and/or morality in Czechia and Slovakia. Master thesis at MCI 'Strategic Management \& Law', summer term 2017, Innsbruck.

Lienbacher, G. (2013). Die dynamische Rechtsprechung des Gerichtshofes der Europäischen Union und ihre Grenzen: Eine Gedankenskizze. In K. Giese, G. Holzinger, \& C. Jabloner (Eds.), Verwaltung im demokratischen Rechtsstaat: Festschrift für Harald Stolzlechner zum 65. Geburtstag (pp. 423-450). Wien: Verlag Österreich.

Louden, R. B. (2012). Virtue ethics. In R. F. Chadwick (Ed.), Encyclopedia of applied ethics (2nd ed., pp. 503-510). London: Academic Press.

Martinsen, D. S. (2015). An ever more powerful court?: The political constraints of legal integration in the European Union. Oxford: Oxford University Press.

Pacey, L. (2016). EU law and ethics-implementation of EU directives referring to ethics and/or morality in the United Kingdom and Republic of Ireland. Master thesis at MCI 'International Business \& Law', summer term 2016, Innsbruck.

Pechstein, M. (2018). Art. 2 EUV [Werte]. In R. Streinz (Ed.), EUV/AEUV: Vertrag über die Europäische Union, Vertrag über die Arbeitsweise der Europäischen Union, Charta der Grundrechte der Europäischen Union (3rd ed.). München: C.H. Beck.

Petrick, J. A. (2008). Integrity. In R. W. Kolb (Ed.), Encyclopedia of business ethics and society (pp. 1141-1144). Los Angeles, London, New Delhi, Singapore: Sage Publications.

Pindyck, R. S., \& Rubinfeld, D. L. (2018). Microeconomics (9th ed.). Harlow, England: Pearson.

Plomer, A. (2018). The duality of human dignity in Europe. In F. Foret \& O. Calligaro (Eds.), European values: Challenges and opportunities for EU governance (pp. 23-45). London: Routledge.

Prainsack, B., \& Buyx, A. (2017). Solidarity in biomedicine and beyond. Cambridge, New York: Cambridge University Press.

Rudigier, J. (2015). Ethics and morality in the European Union-with a special focus on case law of the European Court of Justice. Master thesis at MCI 'International Business \& Law', summer term 2015, Innsbruck.

Sahlin, N.-E. (2018). It's values that matter. In N.-E. Sahlin (Ed.), Science and proven experience: Johannes (pp. 77-86). Lund: Media-Tryck.

Sandel, M. J. (2010). Justice: What's the right thing to do? New York: Farrar, Straus and Giroux.

Sandel, M. J. (2012). What money can't buy: The moral limits of markets. New York: Farrar, Straus and Giroux.

Saurugger, S., \& Terpan, F. (2018). The values of the Court of Justice of the European Union. In F. Foret \& O. Calligaro (Eds.), European values: Challenges and opportunities for EU Governance (pp. 99-115). London: Routledge. 
Sava, G. (2017). EU law and ethics-implementation of EU directives referring to ethics and/or morality in Italy. Master thesis at MCI 'Strategic Management \& Law', summer term 2017, Innsbruck.

Sedmak, C. (Ed.). (2010). Grundwerte Europas: Band 1. Solidarität: Vom Wert der Gemeinschaft. Darmstadt: WBG Wissen verbindet.

Sedmak, C. (Ed.). (2012). Grundwerte Europas: Band 2. Freiheit: Vom Wert der Autonomie. Darmstadt: WBG Wissen verbindet.

Sedmak, C. (Ed.). (2013). Grundwerte Europas: Band 3. Gleichheit: Vom Wert der Nichtdiskriminierung. Darmstadt: WBG Wissen verbindet.

Sedmak, C. (Ed.). (2014). Grundwerte Europas: Band 4. Gerechtigkeit: Vom Wert der Verhältnismässigkeit. Darmstadt: WBG Wissen verbindet.

Sedmak, C. (Ed.). (2015). Grundwerte Europas: Band 5. Toleranz: Vom Wert der Vielfalt. Darmstadt: WBG Wissen verbindet.

Sedmak, C. (Ed.). (2016). Grundwerte Europas: Band 6. Frieden: Vom Wert der Koexistenz. Darmstadt: WBG Wissen verbindet.

Sedmak, C. (Ed.). (2017). Grundwerte Europas: Band 7. Menschenwürde: Vom Selbstwert des Menschen. Darmstadt: WBG Wissen verbindet.

Tansey, R. (2014). The EU's revolving door problem: How big business gains privileged access. In D. Dialer \& M. Richter (Eds.), Lobbying in der Europäischen Union: Zwischen Professionalisierung und Regulierung (pp. 257-268). Wiesbaden: Springer.

Van Hoof, W., \& Pennings, G. (2012). Extraterritorial laws for cross-border reproductive care: The issue of legal diversity. European Journal of Health Law, 19, 187-200. https://doi.org/10.1163/ 157180912 X628226.

Varona Martín, A. (2016). European law and ethics: Implementation of European Union directives referring to ethics and/or morality in Spain. Master thesis at MCI 'International Business \& Law', summer term 2016, Innsbruck.

Open Access This chapter is licensed under the terms of the Creative Commons Attribution 4.0 International License (http://creativecommons.org/licenses/by/4.0/), which permits use, sharing, adaptation, distribution and reproduction in any medium or format, as long as you give appropriate credit to the original author(s) and the source, provide a link to the Creative Commons license and indicate if changes were made.

The images or other third party material in this chapter are included in the chapter's Creative Commons license, unless indicated otherwise in a credit line to the material. If material is not included in the chapter's Creative Commons license and your intended use is not permitted by statutory regulation or exceeds the permitted use, you will need to obtain permission directly from the copyright holder.

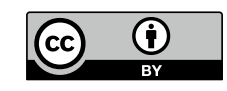

